\title{
Funding and facilitating innovation
}

Citation for published version (APA):

Stolze, B. (2021). Funding and facilitating innovation. [Doctoral Thesis, Maastricht University]. ProefschriftMaken. https://doi.org/10.26481/dis.20210428js

Document status and date:

Published: 01/01/2021

DOI:

10.26481/dis.20210428js

Document Version:

Publisher's PDF, also known as Version of record

\section{Please check the document version of this publication:}

- A submitted manuscript is the version of the article upon submission and before peer-review. There can be important differences between the submitted version and the official published version of record.

People interested in the research are advised to contact the author for the final version of the publication, or visit the DOI to the publisher's website.

- The final author version and the galley proof are versions of the publication after peer review.

- The final published version features the final layout of the paper including the volume, issue and page numbers.

Link to publication

\footnotetext{
General rights rights.

- You may freely distribute the URL identifying the publication in the public portal. please follow below link for the End User Agreement:

www.umlib.nl/taverne-license

Take down policy

If you believe that this document breaches copyright please contact us at:

repository@maastrichtuniversity.nl

providing details and we will investigate your claim.
}

Copyright and moral rights for the publications made accessible in the public portal are retained by the authors and/or other copyright owners and it is a condition of accessing publications that users recognise and abide by the legal requirements associated with these

- Users may download and print one copy of any publication from the public portal for the purpose of private study or research.

- You may not further distribute the material or use it for any profit-making activity or commercial gain

If the publication is distributed under the terms of Article $25 \mathrm{fa}$ of the Dutch Copyright Act, indicated by the "Taverne" license above, 


\section{Funding and facilitating innovation}

Benedikt Stolze 


\section{ISBN}

978-94-6423-207-3

\section{Cover Design}

Emily Jäger

\section{Printed by}

ProefschriftMaken.nl

(C) 2021 Benedikt Stolze 


\section{Funding and facilitating innovation}

\section{DISSERTATION}

to obtain the degree of Doctor at Maastricht University, on the authority of the Rector Magnificus, Prof. Dr. Rianne M. Letschert, in accordance with the decision of the Board of Deans, to be defended in public on Wednesday $28^{\text {th }}$ of April 2021 at 10:00 hours.

by

Benedikt Stolze 


\section{Supervisor}

Prof. Dr. Alexander Brüggen

\section{Co-Supervisor}

Prof. Dr. Edward Huizenga

\section{Assessment Committee}

Prof. Dr. Roger Meuwissen

Prof. Dr. Martin Carree

Prof. Dr. Mandy Cheng

Prof. Dr. Matthias Menter 


\section{Acknowledgement}

It was the $16^{\text {th }}$ of January 2015 , my master's studies at Maastricht University were in full swing and I had just applied for a semester abroad in India, when I received an email that turned out to shape my life for the years to come. My professor, Alexander Brüggen, asked if I were interested in a $\mathrm{PhD}$ position. I learnt that this was not just any request for a conventional $\mathrm{PhD}$ position, but it was an offer to participate in a collaborative research initiative between Maastricht University and one of the leading automotive companies in the world. Anyone in his clear mind that considered a $\mathrm{PhD}$ would have gone above and beyond for an opportunity like this.

Looking back today, I can confess that at the time I was not considering a $\mathrm{PhD}$, I wanted to kickstart my professional career and challenge myself in the business world. Luckily, my dearest advisors and supporters, my parents Hedwig \& Jürgen, asked why I wouldn’t consider this opportunity. In the end, it turned out to be one of the best decisions of my personal development to revisit the idea of doing a $\mathrm{PhD}$ and look at my professor's request again more closely.

Now, four years after beginning my $\mathrm{PhD}$ in January 2016, it is time for me to just be grateful. Alex, you have not only been my Supervisor, you have been a mentor, a friend and, most of all, you have been available 24/7 via Whatsapp for any related or unrelated queries. I'm deeply thankful for your support. You have empowered me to identify and pursue my own research interests. Working with you drove me to tackle problems pragmatically from different perspectives and always focus on the managerial implications. Research without practical relevance is something we don't do. Your words still resonate in my head today and have had a much broader effect on me than it may seem at first. To me your words meant, don't do something, if it doesn't create value or impact. Thank you, Alex. 
My Co-Supervisor, Edward Huizenga, has supported me strongly through my $\mathrm{PhD}$ journey as well. With his extensive practical experience as a partner at Benthurst \& Co., a leading Dutch strategy consultancy, coupled with academic perspective in his role as Professor of Strategy, Innovation and Change, he would always provide valuable feedback to my academic work. For me, his understanding of new business development gave me the chance to challenge academic theoretical fundament with anecdotal evidence from his practical experience. I am convinced that Edward consistently ensured the applicability of my research in practice.

Although I happened to be an external PhD candidate, I tried to tap into the vast experience and in-depth knowledge of my colleagues. In particular, I'd like to thank Christoph \& Frank for supporting me in the process of laying the groundwork for articles. Your feedback has always been to the point and straightforward; something I value to this day. I also want to thank Katlijn for keeping me connected to the home base and providing me with reasons to visit Maastricht University more often. I'm always happy to be there, so hopefully those invitations keep coming.

The benefit of being an external $\mathrm{PhD}$ candidate is that you have more colleagues. For me, those were the colleagues I worked with most of the time. First, I'd like to thank my supervisor, Lars, who gave me the opportunity to pursue my $\mathrm{PhD}$ in the first place. Not only did I receive the opportunity, but I also found an environment that allowed me to strive and excel both in my professional and academic work. To learn about intrapreneurship and gain insights about its success drivers, I could have not created my work without the invaluable support of Martin and Tobi. You guys have not only been great colleagues and supporters of my research, but also extremely pleasant to be around. Thank you for that. Last, but certainly not least, I want to thank my dear colleague and friend Gregor. Your happiness, ambition and wit have always been an inspiration to me. Together we have had a blast in the office and it was you, who made my workday a little less corporate. You know what I mean with that. Thank you! 
I'm very excited about the following paragraphs. Why? Because I can dedicate a few lines of my dissertation to the people who mean the world to me. Mum \& dad, you're simply the best. I would not be the curious and ambitious mind that I am today, if it weren't for you. The same gratitude goes out to my sister, Henrike, if there is one person I can always count on and share my thoughts with, it's you. Thank you for being the best sibling anyone could ever ask for. To my friends, who have accompanied me along the way to my $\mathrm{PhD}$ and beyond, I am deeply thankful for our relationships. Philip, let it be city trips, let it be a podcast, let it be long nights with drinks, parties and great conversations, we've been through it all. I hope that our ways won't part and that we'll have many more chapters to write together. Flo, when you stepped into my life, it changed for the better. Your signature traits are positivity, candidness and charm, none of which I want to miss in my life going forward. I am certain, we will have an incredible time ahead of us. Schmücki, what can I say? You're a smart, good-hearted guy from head to toe with whom I've had endless conversations about academic research and statistics. I thank for that and I know that my refusal to respond to +5 min voice messages will only bring us closer together. Max, we have started our journey together during our master's degree in Maastricht. We share memorable experiences such as a reckless road trip in India or an ambulance ride to a hospital in Düsseldorf. I know, we can always count on each other - thank you. Lars, you've inspired me with your diligence and persistence for as long as I can remember. Until this day, I happily recall the times of flat sharing and early morning workouts.

All in all, it's been a wild ride and I can confidently say that I've grown. I hope that with my academic research I can contribute to the discussion about corporate innovation and intrapreneurship, while also providing some inspiration for aspiring researchers like I was myself a couple of years ago. Thank you again to everyone. 


\section{Table of contents}

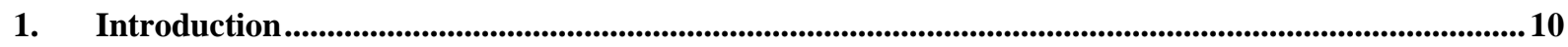

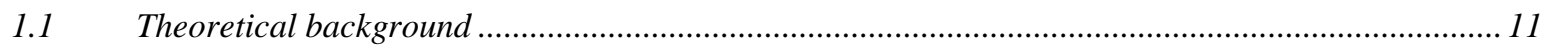

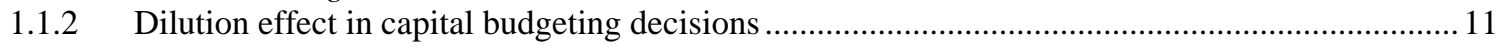

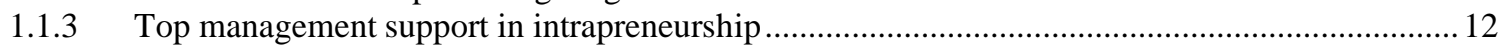

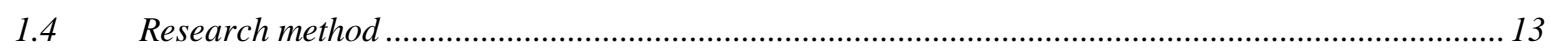

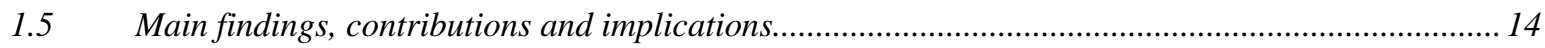

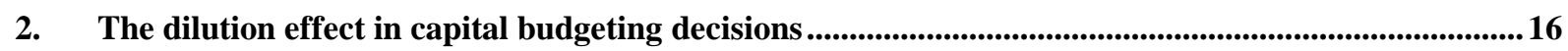

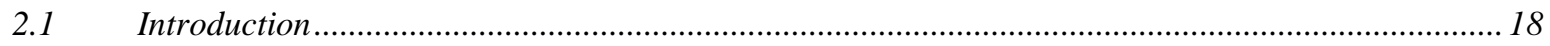

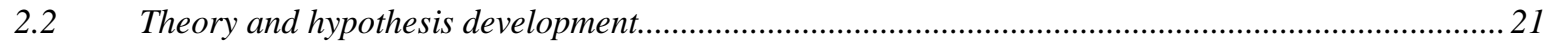

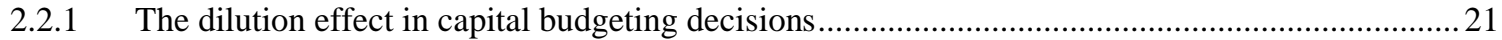

2.2.2 The use of nondiagnostic information types in capital budgeting decisions ................................24

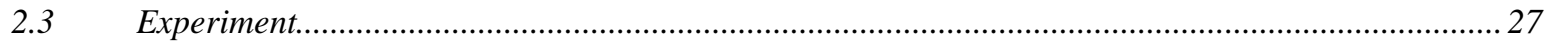

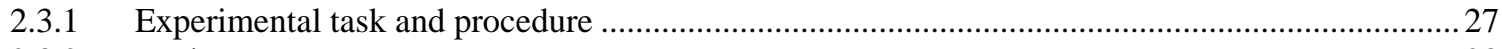

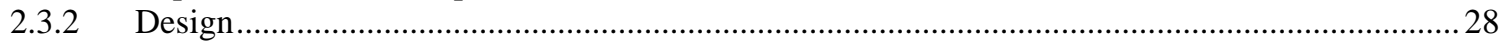

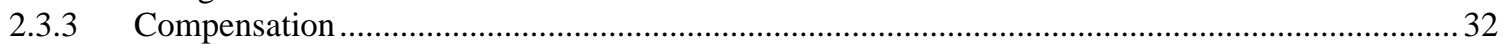

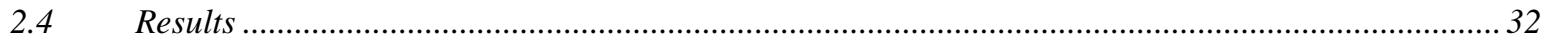

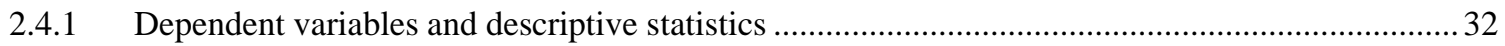

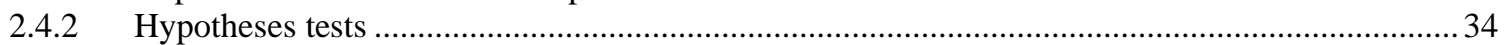

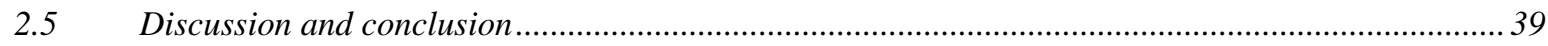

3. An empirical study on the role of top management support in intrapreneurship..............................43

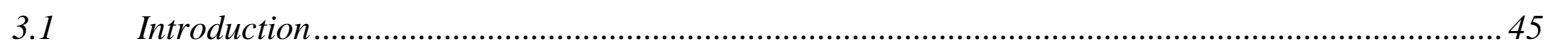

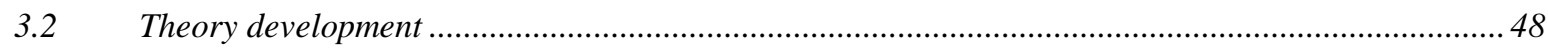

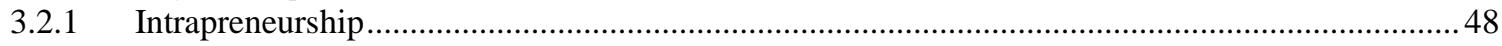

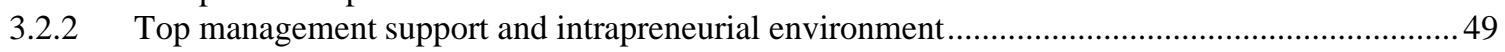

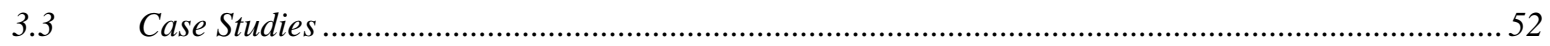

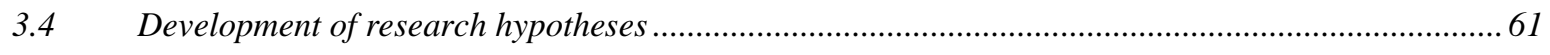

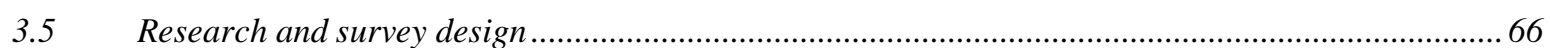

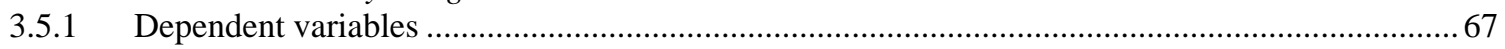

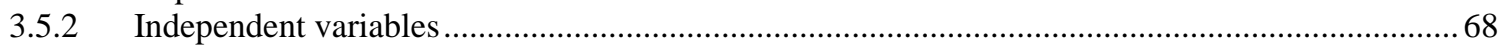

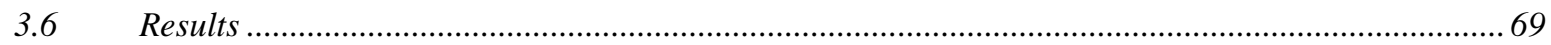

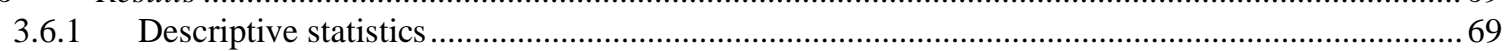

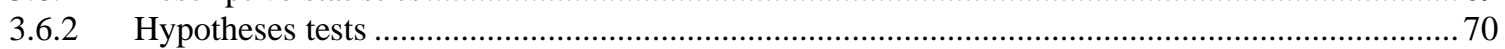

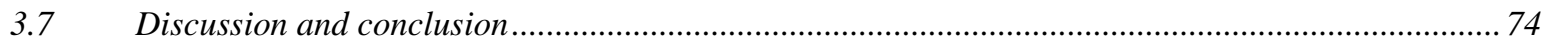

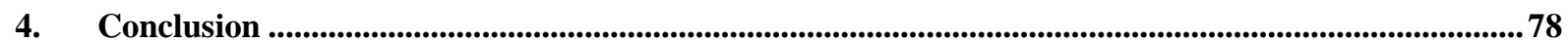

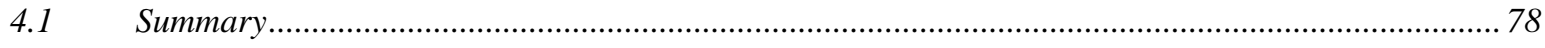

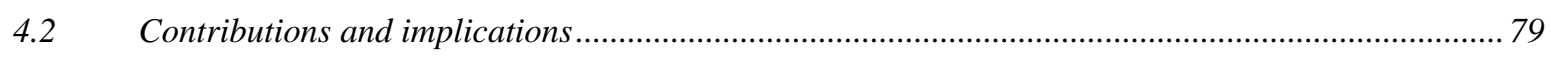

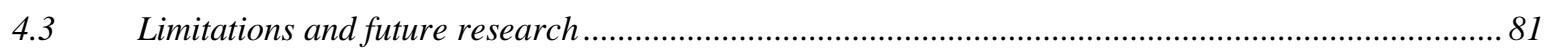

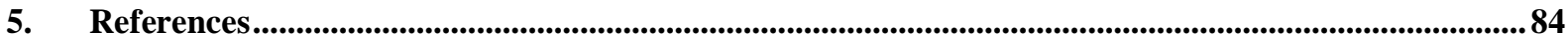

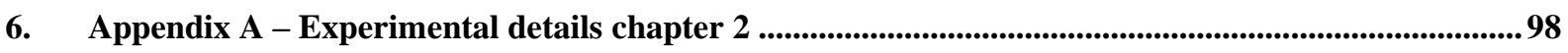

6.1 Part 1 - Experimental flow (exemplary treatment of high risk and 12 information cues).................98

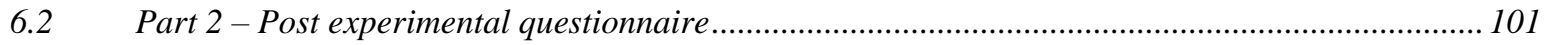


7. Appendix B - Survey details chapter 3 .........................................................................................103

7.1 Part 1-Questionnaire outline for intrapreneurship program managers ...................................... 103

7.2 Part 2 - Survey items for intrapreneur questionnaire ...................................................................... 104

7.3 Part 3-OLS Regression Models \& Sobel Test Mediation ……..................................................... 105

8. Appendix C: Valorization-addendum.................................................................................................106 


\section{Introduction}

For corporations, it is a challenge to innovate. Large organizations are inherently hamstrung by their existing organizational and decision-making processes. These processes have been optimized over decades to deliver and support core business, while minimizing possibility of any deviation, good or bad. This process paralysis manifests itself in two ways, (1) managers are actively discouraged to take risks and (2) innovative ideas are constrained as these would be considered a deviation from existing process structures (Don Lovallo et al., 2020). While top managers, in theory, should be taking risky decisions to create value for stakeholders, the opposite holds true in practice. Top management in large organizations is reluctant to propose and advocate risky projects. Rather than pursuing new business opportunities, managers prefer marginal improvements to the core business. Although this pattern in corporate behavior is far from new (Hammond, 1967), in dynamical changing market environments with new business evolving each and every day across the globe, it is more relevant than ever (Lovallo et al., 2020). To overcome this fallacy, two phenomena can be observed in the corporate world today that are subject to this dissertation.

First, top managers receive immense amounts of information that is supposed to enable decision-making, especially in the allocation of funds to innovation projects. Due to decreasing costs to acquire information, more information is available to managers with the intention to empower and improve decision-making. However, more information may not necessarily the answer to top managers' reluctance to allocate funds to risky projects. More information means that not all information provided is relevant to decision-makers, because managers need to navigate through the data and identify diagnostic from non-diagnostic information. It could therefore be the case that decisions could be negatively impacted rather than improved, which is why in this dissertation I examine whether there are limits of providing information to decision-makers in order to facilitate capital budgeting for risky projects. 
Second, corporations create so-called innovation labs or intrapreneurship centers in which they permit deviations from existing processes in order to fuel to innovative spirit of the organization. It is not uncommon to give pretentious names to these organizational units and locate them in allegedly innovative cities or environments. While some employees consider these units as an opportunity to pursue their entrepreneurial calling, manage an innovation project independently and become an intrapreneur, an entrepreneur in an existing organization, top managers find themselves to be challenged in a setting like this. The reasons for top managers' struggles are manifold, short-sighted corporate incentive structures deem inadequate for innovative undertakings, hierarchies are called into question, technological savviness becomes a prerequisite and de-centralized decision-making is considered the norm. Therefore, in my dissertation, I combine research from finance \& management accounting on capital allocation and decision making with the research from innovation management and intrapreneurship to understand how these two fields must interplay in order to generate company value as well as contributing novel insights to the world of research.

\subsection{Theoretical background}

\subsubsection{Dilution effect in capital budgeting decisions}

Studies in accounting research suggest that traditional financial assessments can be inadequate in capital budgeting tasks, particularly under high risk, and should therefore be complemented with additional information (Chen 2008; Chow and Van der Stede 2006). According to the results of Chen (2008), discounted cash flow (DCF) techniques can be partially substituted by nonfinancial information. Some research even state that additional nonfinancial information has the same relevance as financial information in capital budgeting. Although I recognize this research as well as decision-makers' desire to be as informed as possible, I hypothesize that more information increase stress for decision-makers to maneuver through their own information systems (Piercy 2018). The potential of an information overabundance coupled 
with the risk of providing non-diagnostic information, meaning information that is irrelevant to assess a decision outcome, can cause a dilution effect to occur such that suboptimal capital allocations are taken (Troutman and Shanteau 1977; Nisbett et al. 1981; Hackenbrack 1992; Shanteau 1992; Glover 1997; Shelton 1999; Hotaling et al. 2015). The dilution effect occurs when nondiagnostic information is added to diagnostic information in a decision process, which can negatively influence decision outcome. This phenomenon has been studied in a variety of decision tasks, yet my research is the first to transfer this concept to risky capital budgeting tasks. The reasoning for applying this concept to the area of capital budgeting is attributed to the inherent complexity of capital budgeting stemming from (1) various information sources, (2) different types of information and (3) uncertainty about the underlying parameters the restrict reliable assessment. Understanding the underlying mechanisms of potential dilution effects has significant influence on the design of management information systems for risky project assessments and the presentation of information to decision-makers in general.

\subsubsection{Top management support in intrapreneurship}

Intrapreneurship literature describes intrapreneurial activity as a bottom-up initiative by an entrepreneurially-minded individual in an existing organization that attempts to innovate the firm outside of the core business (Antoncic \& Hisrich, 2001; Hornsby et al. 2003; Dess \& Lumpkin 2005). Due to its explorative nature and divergence from standard corporate processes, intrapreneurship requires support and safeguarding from top management. For this reason, top management needs to back intrapreneurial activity on different levels for instance (1) goal-setting involvement, (2) resource allocation, (3) project commitment and sponsorship, as well as (4) defending initiatives against adverse opinions in the organization.

Prior empirical research in related fields has indicated that especially resource commitment and adequate leadership provide positive influence on new product development (Swink 2000). Zirger and Maidique (1990) find that top management attention usually attracts talented 
workforce, which could also be an alleviating factor in intrapreneurship, given that top managers support the initiative. Similarly, however, top management support may also turn into a detrimental force, if controlling of intrapreneurial activities take over (Gersick et al. 1990) because intrapreneurs become constrained in their individual pursuit of their project. This effect is worsened by commonly near-term oriented incentive schemes by top managers that lay emphasis on short-term wins instead of investing in long-term innovation initiatives like intrapreneurship. Moreover, a lack of technical expertise among top managers can also have negative impact on intrapreneurship, because for breakthrough innovation deep technical or industry-overarching competence may be required to understand the customer value of a new business idea (Takeuchi \& Nonaka 1986; Swink 2000). To be successful in a large organization, intrapreneurs also require an environment that allows the pursuit of innovative undertakings by deviating from restricted corporate processes. Besides sufficient resources, literature suggests that intrapreneurs can benefit from sufficient time to follow their initiatives (Brazeal, 1993; Schuler, 1986; Kuratko et al., 1990), decision autonomy (Mintzberg, 1973; Khandwalla, 1973; Slevin \& Covin, 1990; Covin \& Slevin, 1989; Barringer \& Bluedorn, 1999), collaboration opportunity (Bantel \& Jackson, 1989; Gapp \& Fisher, 2007; Alpkan et al., 2010). These aspects can both have positive implications for the success, but also for the innovativeness of the project.

\section{$1.4 \quad$ Research method}

To examine my research questions, I pursued a mixed method approach (Denscombe, 2008; Yin, 2006), where I performed a laboratory experiment with students from Maastricht University, I conducted 10 case based interviews with managers running intrapreneurship programs in MNCs across Europe and I ran a survey among 63 intrapreneurs in a large manufacturing firm in Germany. To investigate decision behavior of individuals, a laboratory environment creates a controlled abstract setting that holds everything constant except for the 
manipulations of interest. Further, experiment participants are randomly allocated to different treatments. Hence, the experimental method isolates the effects under examination and tests the cause-effect-relationship. Although laboratory environments do not mimic a real work setting, it allows me control for exogeneous influences, therefore it is ideal to investigate decisionmaking behavior as part of my first research question.

For my second study, I chose to follow a more explorative approach by conducting expert interviews to generate an understanding of how intrapreneurship is managed in practice. This procedure allowed me to complement the current state of research on the topic and investigate the function and duties of top managers in this context more closely. It also helped to shed light on the causal direction between TMS and intrapreneurship and supported the development of my conceptual model that I used for my subsequent survey analysis. Further, I was able to extract what an intrapreneurial environment would look like in a large organization. Based on these insights, my survey, which I issued to 119 intrapreneurs within a large European corporation, tested my hypotheses concerning the role of top management support and intrapreneurial environment in intrapreneurship. The quantitative data enabled an empirical analysis to test the hypothesized relationships and thereby providing substantiated evidence for my research question.

\subsection{Main findings, contributions and implications}

The findings of my dissertation show that to improve capital budgeting in risky innovation projects more information is not necessarily better, particularly when non-diagnostic information is also provided. I find that more non-diagnostic information actually causes suboptimal decision-making, as the overabundance of information creates a dilution effect such that funds allocated to risky projects lowers. My results show that this effect is more pronounced with an increasing number of non-diagnostic information cues. I also find that decision-makers exhibit preferences towards particular types of information cues, such that 
nonfinancial information is only preferred in the absence of risk and information load, whereas when decision risk is high, preferences lean towards more familiar financial information. These findings contribute to a growing stream of literature on management information systems (MIS). Despite the trend to measure as many things as possible, my results give reason to believe that there are limits to this and under some conditions, too much information can have detrimental effects, especially when diagnostic and nondiagnostic information is provided jointly. Hence, capital budgeting for risky projects needs MIS that focus on a selected number of information cues that bear diagnostic power to the decision outcome.

Further, my findings indicate that the role of top managers to facilitate intrapreneurial innovation projects is relevant to lend organizational backing. I was able to establish the causal relationship that TMS is a determinant for intrapreneurship. Based on my interview insights and survey analysis, top management support is essential for intrapreneurship to really flourish. I reveal that top management support has a positive influence on the success of intrapreneurship projects, while it has arguably a negative impact on project innovativeness. For one, top managers can move aside organizational obstacles to ensure progress for the project, for the other, top management support can also cause interference and a lack of technical knowledge may restrain the innovational power of the project. I also find that top managers need to shape an entrepreneurial environment that is particularly geared towards networking amongst colleagues in the same organization, because this is a key driver for intrapreneurs' innovativeness. Under these conditions, top managers can take a contributing role for innovative undertakings and empower those who pursue intrapreneurial projects. 
2. The dilution effect in capital budgeting decisions 


\section{Abstract}

With large amounts of information available, managers find it increasingly challenging to distinguish between diagnostic and nondiagnostic information when making decisions. I investigate how decision makers take information into account in capital budgeting decisions and what impact nondiagnostic information has on the decision outcome, hence, whether nondiagnostic information leads to a dilution effect. I also consider whether risk and information load in capital budgeting decisions is associated with a focus on financial or nonfinancial nondiagnostic information. In an experiment I manipulate the level of risk of a decision context and the amount of nondiagnostic information provided. I find evidence that the provision of nondiagnostic information cues stimulates a dilution effect coupled with lower investments. I observe this effect to become more pronounced with an increasing number of nondiagnostic information cues. My results also indicate that decision makers in a high-risk scenario commit to lower investments, which in general remains the case when more nondiagnostic information cues are provided. I also find that decision makers only prefer nonfinancial information in the absence of risk and cognitive load, whereas in high-risk decision contexts decision makers use more familiar financial information cues when exposed to more nondiagnostic information cues. My findings have implications for the design of management information systems. Despite the trend to measure as many things as possible to support capital budgeting decisions, I show that the benefits of increasing the amount of information have limits, particularly when diagnostic and nondiagnostic cues are presented jointly in capital budgeting decisions. 


\subsection{Introduction}

Managers receive large amounts of information every day that is supposed to support decision making. As such, part of their job is to distinguish between diagnostic and nondiagnostic information when making strategic decisions. Diagnostic information is information that is at least remotely predictive of a certain outcome. With the rise of information systems and the decreasing costs of obtaining information, more information is available to managers, but it is not necessarily relevant to the decisions they need to make and thus nondiagnostic (BrownLiburd et al. 2015; McKinsey Global Institute 2017). In this study, I investigate how decision makers take information into account in capital budgeting decisions and what impact nondiagnostic information has on the decision outcome. This research is particularly important from an accounting perspective because the provision of information is a key purpose of management information systems (MIS). Nondiagnostic information should have no effect on decisions, and only diagnostic information should drive decision processes. However, prior research (Troutman and Shanteau 1977; Hackenbrack 1992; Shanteau 1992; Glover 1997; Shelton 1999; Hotaling et al. 2015) has demonstrated that managers are influenced by nondiagnostic information and are susceptible to a dilution effect (Nisbett et al. 1981; Hoffman and Patton 1997). This effect occurs when nondiagnostic information added to diagnostic information changes a decision, which can negatively influence outcomes. While dilutive effects of nondiagnostic information have been studied in various decision scenarios, such as psychological judgments (Gaeth and Shanteau 1984), perceptual decision making (Hotaling et al. 2015), auditing (Glover 1997; Shelton 1999), consumer decisions (Meyvis and Janiszewski 2002), and uncertainty judgments in general (Tversky and Kahneman 1973), these effects have scarcely been investigated in the context of capital budgeting decisions.

For many firms, capital budgeting decisions are a complex process because (1) information stems from a variety of sources, (2) different types of information need to be processed, and (3) 
uncertainty about underlying parameters hinders reliable assessments (Chow and Van der Stede 2006; Chen 2008). The finance literature generally advocates to rely on net present value (NPV) analysis in capital budgeting decisions as an aggregate of all decision-relevant information (Myers 1984; Ross 1995; Banker et al. 2004), yet it is evident that in practice decision makers consider other information as well (Cardinaels and van Veen-Dirks 2010; Turner and Coote 2018). In my study, I concur that NPV is the deterministic decision measure and that any other information is either (1) redundant because it is already contained in the NPV analysis, or (2) uncorrelated with the desired outcome; hence, I refer to it as nondiagnostic information. Based on arguments from prior literature (Anderson 1971), I expect that when provided together with diagnostic information (e.g., NPV) in a capital budgeting decision task, nondiagnostic information creates a dilution effect that causes decision makers to deviate from an NPV-only assessment. Likewise, I anticipate the more nondiagnostic information decision makers receive, the stronger the dilution effect will be. An interesting additional question relates to the type of nondiagnostic information (i.e., whether it is nonfinancial or financial) and decision makers' preference to favor one over the other in a capital budgeting decision. Based on evidence from prior research on high risk decision contexts, i.e. venture capital or information system investments, decision makers' familiarity with particular information cues or metrics drives decision confidence (Tam 1992; Ahmed 2013). Similarly, I presume that in high-risk decision scenarios with exposure to nondiagnostic information, decision makers revert to familiar information cues when confronted with growing amounts of nondiagnostic information. Conversely, I only expect decision makers to experiment with unfamiliar, nonfinancial information in their decision processes when the decision context exhibits low risk while only a limited amount of nondiagnostic information cues is provided. Insights from this examination provide novel implications for MIS design in capital budgeting regimes. 
To test my predictions, I ran an experiment with 120 participants conducting 6 consecutive capital budgeting decisions in which I randomly assigned participants to either a high- or lowrisk scenario. I manipulated the amount of nondiagnostic information cues available in both treatments. I kept the composition of nondiagnostic information cues evenly distributed between financial and nonfinancial cues across all treatments with nondiagnostic information provided. Results of my experiment support the idea that decision makers use nondiagnostic information in capital budgeting decisions. I find evidence that the provision of nondiagnostic information cues stimulates a dilution effect in capital budgeting decisions coupled with lower investments. In fact, I observe this effect to become more pronounced with an increasing number of nondiagnostic information cues. Further, my analysis indicates that analogous to prior research decision makers in a high-risk scenario commit to lower investments, which in general remains the case when more nondiagnostic information cues are provided. With a growing number of nondiagnostic information cues provided, decision makers tend to utilize more information cues, while evidence of my experiment also shows that a larger share of nonfinancial information cues is used in the absence of risk and cognitive load.

Although an extensive body of literature centers on the importance of relevant information in a capital budgeting decision (Larcker 1981; Sharda et al. 1988; Swain and Haka 2000), remarkably little is known about the effect of nondiagnostic information on a capital budgeting decision. My study contributes to the growing stream of literature on the dilution effect. I underline the importance of information selection in capital budgeting decision tasks, and my findings provide novel implications for MIS design. Despite the trend to measure as many things as possible to enhance the quality of decisions and to facilitate capital budgeting decisions, I show that the benefits of increasing the amount of information have limits, particularly when diagnostic and nondiagnostic cues are presented jointly in capital budgeting 
decisions. Furthermore, I explore decision scenarios that may produce outcomes beyond those expected to fuel future research efforts.

The remainder of this paper is structured as follows. First, I provide a comprehensive literature review and hypotheses development. Then, I describe the experimental method before the results are presented. Lastly, I discuss my findings and conclude.

\subsection{Theory and hypothesis development}

Recent studies in accounting suggest that traditional financial assessment tools can be inadequate and should be augmented with additional information. Chow and Van der Stede (2006) surveyed 128 manufacturing firms and concluded that a combination of financial, nonfinancial, and subjective measures would improve management decisions. Research by Chen (2008) focuses on capital budgeting and shows that traditional discounted cash flow (DCF) techniques can be partially substituted by nonfinancial information. Related experimental evidence from Turner and Coote (2018) reports that nonfinancial information has relevance similar to that of financial information for decision makers in capital budgeting regimes. Although I recognize this research, it appears as if managers do not receive expedient support from all this extra information; instead, they find themselves under stress, confronted with the task of maneuvering their own information systems (Piercy 2018). While the adverse effects of a growing information load are well recognized, the influence of potential overabundance of nondiagnostic information is scarcely understood, which is why I investigate the dilutive effect of such information in capital budgeting decisions (Ackoff 1967; Eppler and Mengis 2004).

\subsubsection{The dilution effect in capital budgeting decisions}

The literature proposes different reasons for why managers integrate nondiagnostic information into decision-making processes. For a capital budgeting decision, or in fact for any significant decision that affects prospective company performance, managers expect to be extensively 
informed. This expectation is often accompanied by risk as well as a manager's fear of making wrong decisions (Tversky and Kahneman 1973; Jackall 1988). In turn, decision makers demand additional information to gain a better understanding of the task at hand. Additional information, however, can contain low-validity or nondiagnostic information cues (Ackoff 1967; Brown-Liburd et al. 2015).

Kahneman and Tversky (1973), for example, show that the mere presence of information induces managers to take nondiagnostic cues into account for decision-making purposes. Studies by Shanteau (1992) and Gorla et al. (2010) arrive at the same conclusion. One problem for managers confronted with various pieces of information is distinguishing what information is diagnostic and what is nondiagnostic. This discernment becomes particularly difficult in capital budgeting decisions, as the capital budgeting literature suggests that various types of information, such as financial, nonfinancial, and subjective criteria, as well as the various sources of information, could potentially be relevant for decision makers (Chow and Van der Stede 2006; Chen 2008; Turner and Coote 2018).

Prior literature has established different reasons why a dilution effect occurs. Studies by Doherty and other researchers identify a so-called "pseudodiagnosticity effect," whereby subjects even prefer nondiagnostic cues over diagnostic ones when both are available (Doherty, Mynatt, et al. 1979; Doherty, Schiavo, et al. 1981). Individuals thus seem to have a tendency to ignore base rate data and to seek confirmatory evidence. This phenomenon is quite common in practice: managers who are interested in pursuing a pet project search primarily for data that supports their claim that the project is worthwhile for the company to convince their superior. The most common explanation in the social judgment literature of the dilution effect relies on the similarity heuristic (Sprinkle 2003; Fein and Hilton 1992; Tetlock and Boettger 1989; Nisbett et al. 1981). The similarity heuristic is an approach by which decision makers form their choices based on the perceived similarity between a mental model that produces a certain 
outcome and the information provided. Diagnostic information is proposed to represent the desired outcome, while nondiagnostic information does not. Hence, more nondiagnostic information reduces the representativeness of the desired outcome and dilutes the decision maker's judgment. Although this model is suitable for probability judgments in social experiments, as such, it disregards decision makers' general risk-taking propensity and subjective assessments of information relevance, which are both crucial factors in capital budgeting decisions (Gigerenzer and Gassmaier 2011).

In general, more information in decision tasks raises concerns about the dilution effect because chances to collect nondiagnostic information increase (Nisbett et al. 1981). To prepare major capital budgeting decisions, the gathering and processing of different types of information from a variety of sources is required for a solid decision-making basis. Research by Chewning and Harrell (1990) finds that in financial distress decisions, more information cues lead to more cue utilization, which in turn produces lower decision quality. Sprinkle's (2003) analysis of experimental research in managerial accounting shows that decision makers integrate potentially dilutive (e.g., nondiagnostic) information into their decision processes in an effort to consider all the information provided for a decision task. This phenomenon could also induce capital budgeting decision makers to pay attention to nondiagnostic information when forming their judgment. Based on findings by Kahneman and Tversky (1973) as well as Hackenbrack (1992), the integration of nondiagnostic information is even more pronounced when such information is presented to decision makers as being more salient. Salience is primarily determined by the capacity to capture decision makers' attention. It can be attributed to the presentation of a specific piece of information or to the sheer amount of a particular kind of information. Therefore, if more nondiagnostic information cues are provided in a decision task, some, if not all, of these additional information cues are presumably incorporated into the decision-making process. Following the aforementioned arguments, I expect nondiagnostic 
information to dilute decision makers' judgment in capital budgeting decisions such that investment amounts decrease, and even more so, when the amount of nondiagnostic information increases. Hence, I formulate the following two hypotheses:

H1a: The provision of nondiagnostic information creates a dilution effect.

$H 1 b$ : The more nondiagnostic information provided, the stronger the dilution effect in capital budgeting decisions.

\subsubsection{The use of nondiagnostic information types in capital budgeting decisions}

While effects of risk and cognitive load on investment behavior have been comprehensively studied (Lam et al., 2011; Hoffmann et al., 2013; Agnew and Szykman, 2005) and can also be observed in my research, the subsequent question of what type of nondiagnostic information (i.e., financial versus nonfinancial information) investors consider in their capital budgeting decision process in light of high risk and cognitive load, and why, adds novelty.

Prior studies have investigated how capital budgeting tasks are facilitated in organizations using financial information (Mao 1970; Burns and Walker 1997; Verbeeten 2006; Chen 2008). A common method to evaluate the attractiveness of investment options involves financial analysis, namely DCF techniques, that consider the value of a project as the discounted sum of future cash flows (e.g., the NPV; Berk and DeMarzo 2007). Although NPV is widely recognized as a comprehensive, definitive financial decision measure, NPV has some limitations due to an often limited accuracy of input variables (Sundem 1975; Myers 1984; Ross 1995; Verbeeten 2006; Chen 2008). Market environments rattled by political instability and fluctuating interest and exchange rates pose a particular challenge because qualitative risks need to be translated into adjusted discount rates for adequate decision making (Chittenden and Derregia 2015). For unstructured projects, such as new product developments, assessing cash flow timing reliably can also be difficult (Gorry and Morton 1989). To assess economic viability in risky new product developments, firms have been found to be more likely to 
complement traditional DCF methods with strategic, nonfinancial insights (Chen 2008; Hoff and Wood 2008).

In order to overcome the limitations of DCF techniques, many authors in the capital budgeting field have proposed the introduction of nonfinancial information in project evaluation processes (Hoque and James 2000; Hoque 2005; Verbeeten 2006; Chen 2008). Nonfinancial information is data that, contrary to accounting and market measures (the 'financial ones') do not refer to 'bottom line' results or stock returns, but rather to internal processes, customers, and macroeconomic indicators (Banker et al. 2000; Ittner and Larcker 2003; Chow and Van der Stede 2006). The investment planning literature refers to nonfinancial information as "the other recommended approach" to use beyond traditional capital budgeting methods (Chen 2008). Specifically, the use of nonfinancial information is suggested to those organizations that, for different reasons, cannot reliably estimate DCFs. In fact, the complexity in calculating DCF constitutes one of the main reasons for why nonfinancial information gained importance in the 1990s (Burns and Walker 1997; Pike 1996). Low and Siesfeld (1998) find further support for the role of nonfinancial information in major investors' decision making. Specifically, they show that when analysts took nonfinancial measures like market share and customer retention into account, forecasts were more accurate. Nonfinancial information is considered valuable when risk is high; in such situations, financial information is considered of less value because of its rather aggregated nature and tendency to be backward looking.

Although accounting literature provides reasoning for why decision makers are well-advised to integrate nonfinancial information into their capital budgeting decision process, findings of prior research on individuals' behavior in risky and cognitively demanding tasks suggest an alternative course of action by decision makers. Banker et al. (2004) investigate how decision makers trade off financial with nonfinancial performance metrics in a balanced scorecard. The results indicate that if an integration nonfinancial performance metrics did not imply a decline 
in short term financial gain, only then nonfinancial information was considered by decision makers. From a management accounting standpoint, Bhimani and Langfield-Smith (2007) discover similar preoccupations by individuals in strategy development and implementation tasks. While greater emphasis is placed on financial information in strategy implementation, nonfinancial information comes into play in strategy development, where it compliments financial information. Both Banker et al. and Bhimani and Langfield-Smith underline decision makers' predominant focus on financial metrics, particularly to ensure short term financial performance.

Psychology researchers Tversky and Kahneman (1973; 1974) provide an additional line of reasoning for why decision makers would revert to using financial information in a capital budgeting task. The concept of familiarity heuristic conveys that in decision scenarios where individuals experience a high cognitive load induced by risk or an overabundance of information, they tend to regress to a state of mind where familiar information cues are predominantly integrated into the decision process (Whitney et al., 2008; Gerhardt et al., 2013; Benjamin et al., 2013). Familiar in this context means that individuals have either been acquainted with that type of information or that they have used it previously in a similar task. In capital budgeting decision, nonfinancial information is thought of as a novel, complementary information type that shall be used in addition to traditional financial information, in that regard, nonfinancial information can be considered rather unfamiliar to decision makers in this context. It is for that reason, I concur with the general consensus advocated in accounting literature to integrate nonfinancial information into capital budgeting decisions, however, I hypothesize to only find this to be the case in absence of risk and cognitive load in the decision scenario, because otherwise, I expect decision makers to revert to familiar financial information in their decision process. Hence, I propose the following hypothesis: 
H2: In capital budgeting decisions, nonfinancial information is used more in the absence of risk and cognitive load.

\subsection{Experiment}

I ran an experiment with 120 students at a Dutch university enrolled in economics and/or international business studies, hence having some theoretical experience with investment decisions from their courses. The average age of the participants was 21.2 years, and 62 percent were female. All participants had participated in prior experiments and thus had some familiarity with laboratory experiments. I conducted the experiment using computer software (z-Tree; Fischbacher 2007) and ensured participants' anonymity by using randomly drawn experimental identification (ID) numbers. Participants were compensated based on their performance. The experiment lasted about 45 minutes.

\subsubsection{Experimental task and procedure}

Participants were randomly allocated to the different experimental treatments (Table 1) and received the instructions explaining the capital budgeting decisions they would be facing in the experiment. The flow of the experiment can be viewed in Appendix A - Part 1. In my experiment, participants assumed the role of corporate managers taking capital budgeting decisions. In particular, participants had to decide how much of a fixed budget of 100,000 Experimental Currency Units (ECU) they wanted to invest in a risky option. Participants were asked to freely allocate their budget to a risky option (Investment A) and/or a risk-free alternative (Investment B). ${ }^{1}$ There were six consecutive decisions to be made, that would allow us to observe consistent behavior across decision rounds. In my instructions, I provided four example decisions and outcomes to illustrate the experimental task. Participants had to pass an

\footnotetext{
${ }^{1}$ Participants had to actively allocate an investment amount to Investment $A$, and the remaining budget was automatically allocated to the risk-free alternative. Participants were fully aware of this allocation scheme.
} 
understanding quiz on the provided information and the compensation system of their task before proceeding to the actual experiment as described in Table 2.

TABLE 1

Experimental treatment groups

\begin{tabular}{|l|l|l|}
\hline & Low Risk & High Risk \\
\hline 0 information cues & Treatment 1 & Treatment 2 \\
\hline 6 information cues & Treatment 3 & Treatment 4 \\
\hline 12 information cues & Treatment 5 & Treatment 6 \\
\hline
\end{tabular}

\section{TABLE 2}

\section{Sequence of Experimental Procedures}

1. Each participant was randomly assigned to one of six treatments.

2. Participants received instructions on the experiment, explanation on the experimental currency, and examples of the upcoming task.

3. Participants had to complete a quiz on the given information and compensation system of the upcoming task before continuing.

4. Each participant was presented an investment opportunity consisting of the risky investment project (Investment A) and the risk-free alternative (Investment B)

5. Each participant was asked to analyze the investment opportunity and allocate his or her provided investment budget to Investment A and Investment B.

6. For treatments 3-6, participants needed to indicate which of the given information cues had been used for their capital budgeting decision.

7. Each participant was presented the next investment opportunity.

8. At the end of six rounds, all participants were informed about their performance-based compensation.

9. Each participant answered a post-experiment questionnaire (demographics, manipulation checks, etc.).

\subsubsection{Design}

I manipulated two different variables. One variable is the level of risk inherent in the risky project presented to the participants. I manipulate risk by different levels of variance in the payoff outcomes of the risky project. While the variance of payoff outcomes is extremely high for one half of the treatments, it is significantly lower for the other half (see Table 3). The other 
variable I manipulated is the amount of nondiagnostic information provided to the participant for the evaluation of the risky project, ranging from zero to six to twelve nondiagnostic information cues. ${ }^{2}$ I selected the information cues based on relevant literature from the capital budgeting domain (Hoque and James 2000; Hoque 2005; Larcker 1981). Both settings included an even share of financial and nonfinancial information cues. The information cues assumed binary values that would either indicate favorable or unfavorable conditions for Investment A. Moreover, all participants received the expected NPV of Investment A as well as the lower and upper bound of possible outcomes. The expected NPVs and outcome ranges varied incrementally across the decision rounds, ensuring homogeneous observations with respect to these measures. While the upper and lower bound of possible outcomes had a substantially wider range in the high-risk treatments, the expected NPV remained the same in each decision round for all treatments to ensure comparability between treatments (Table 3).

\footnotetext{
${ }^{2}$ All participants were aware that this information had no diagnostic value for the outcome of Investment A.
} 


\section{TABLE 3}

\section{High Risk}

\section{Proposal of the risky company investment project:}

"You are presented a company investment project for an entirely new product development that is to be introduced in a highly volatile market in which your company has little operational experience."

\begin{tabular}{|l|l|l|l|l|l|l|}
\hline & $\begin{array}{l}\text { Decision } \\
\text { Round 1 }\end{array}$ & $\begin{array}{l}\text { Decision } \\
\text { Round 2 }\end{array}$ & $\begin{array}{l}\text { Decision } \\
\text { Round 3 }\end{array}$ & $\begin{array}{l}\text { Decision } \\
\text { Round 4 }\end{array}$ & $\begin{array}{l}\text { Decision } \\
\text { Round 5 }\end{array}$ & $\begin{array}{l}\text { Decision } \\
\text { Round 6 }\end{array}$ \\
\hline Lower Bound Outcome & 5,000 & 1,000 & 2,000 & 0 & 6,000 & 7,000 \\
\hline Upper Bound Outcome & 193,000 & 201,000 & 198,000 & 204,000 & 190,000 & 187,000 \\
\hline $\begin{array}{l}\text { Expected Net Present } \\
\text { Value }\end{array}$ & $\mathbf{9 9 , 0 0 0}$ & $\mathbf{1 0 1 , 0 0 0}$ & $\mathbf{1 0 0 , 0 0 0}$ & $\mathbf{1 0 2 , 0 0 0}$ & $\mathbf{9 8 , 0 0 0}$ & $\mathbf{9 7 , 0 0 0}$ \\
\hline Range & 188,000 & 200,000 & 196,000 & 204,000 & 184,000 & 180,000 \\
\hline
\end{tabular}

\section{Low Risk}

\section{Proposal of the risky company investment project:}

"You are presented a company investment project for an incremental product extension that is to be introduced in a very stable market in which your company has extensive operational experience."

\begin{tabular}{|l|l|l|l|l|l|l|}
\hline & $\begin{array}{l}\text { Decision } \\
\text { Round 1 }\end{array}$ & $\begin{array}{l}\text { Decision } \\
\text { Round 2 }\end{array}$ & $\begin{array}{l}\text { Decision } \\
\text { Round 3 }\end{array}$ & $\begin{array}{l}\text { Decision } \\
\text { Round 4 }\end{array}$ & $\begin{array}{l}\text { Decision } \\
\text { Round 5 }\end{array}$ & $\begin{array}{l}\text { Decision } \\
\text { Round 6 }\end{array}$ \\
\hline Lower Bound Outcome & 48,000 & 44,000 & 45,000 & 43,000 & 49,000 & 50,000 \\
\hline Upper Bound Outcome & 150,000 & 158,000 & 155,000 & 161,000 & 147,000 & 144,000 \\
\hline $\begin{array}{l}\text { Expected Net Present } \\
\text { Value }\end{array}$ & $\mathbf{9 9 , 0 0 0}$ & $\mathbf{1 0 1 , 0 0 0}$ & $\mathbf{1 0 0 , 0 0 0}$ & $\mathbf{1 0 2 , 0 0 0}$ & $\mathbf{9 8 , 0 0 0}$ & $\mathbf{9 7 , 0 0 0}$ \\
\hline Range & 102,000 & 114,000 & 110,000 & 118,000 & 98,000 & 94,000 \\
\hline
\end{tabular}

All participants were aware that Investment A could only assume the lower or higher bound of the possible outcome ranges with equal probability. In all decision rounds, Investment B had the same NPV as Investment A in order to avoid arbitrage. Further, to ensure participants' understanding of the information cues, their respective values I issued an overview including explanations (Table 4). 


\section{TABLE 4}

\begin{tabular}{|c|c|c|c|}
\hline Information Cue & Explanation & $\begin{array}{l}\text { Unfavorable } \\
\text { Level }\end{array}$ & $\begin{array}{l}\text { Favorable } \\
\text { Level }\end{array}$ \\
\hline Net cash flow ${ }^{\mathrm{a}}$ & $\begin{array}{l}\text { A project's net cash flow is the sum of } \\
\text { cash inflows subtracted by the sum of } \\
\text { cash outflows. }\end{array}$ & Low & High \\
\hline Timing of cash flow ${ }^{\mathrm{a}}$ & $\begin{array}{l}\text { The timing of cash flow indicates } \\
\text { whether initial cash outflows are } \\
\text { recuperated by cash inflows at an early } \\
\text { stage or at a later stage of the project } \\
\text { duration. }\end{array}$ & Late & Early \\
\hline Interest rate ${ }^{\mathrm{a}}$ & $\begin{array}{l}\text { Interest rates express the cost of } \\
\text { borrowing money. }\end{array}$ & High & Low \\
\hline Project duration $^{\mathrm{b}}$ & $\begin{array}{l}\text { Project duration expresses the time } \\
\text { horizon of a project. }\end{array}$ & Long & Short \\
\hline Product sales ${ }^{\mathrm{b}}$ & $\begin{array}{l}\text { Product sales indicate the projected } \\
\text { number of product sales in the given } \\
\text { project. }\end{array}$ & Low & High \\
\hline Product costs $^{\mathrm{b}}$ & $\begin{array}{l}\text { Product costs indicate the expected direct } \\
\text { costs per product produced in the given } \\
\text { project. }\end{array}$ & High & Low \\
\hline Product test results $^{\mathrm{a}}$ & $\begin{array}{l}\text { Product test results comprise how } \\
\text { satisfied customers were with their first } \\
\text { experience with the new product and if } \\
\text { customers exhibited willingness to pay } \\
\text { for the new product. }\end{array}$ & Weak & Strong \\
\hline $\begin{array}{l}\text { Inflation rate in the } \\
\text { target market }\end{array}$ & $\begin{array}{l}\text { Inflation rate shows the rate at which } \\
\text { consumer prices are increasing and, } \\
\text { consequently, the purchasing power of } \\
\text { consumers is falling. }\end{array}$ & High & Low \\
\hline $\begin{array}{l}\text { Projected GDP } \\
\text { growth rate in the } \\
\text { target market }\end{array}$ & $\begin{array}{l}\text { The projected GDP growth rate indicates } \\
\text { the pace at which an economy is expected } \\
\text { to grow in the near future. }\end{array}$ & Low & High \\
\hline $\begin{array}{l}\text { Projected industry } \\
\text { growth rate in the } \\
\text { target market }{ }^{\mathrm{a}}\end{array}$ & $\begin{array}{l}\text { The projected industry growth rate } \\
\text { indicates the rate at which sales of an } \\
\text { industry are expected to grow in the near } \\
\text { future. }\end{array}$ & Low & High \\
\hline $\begin{array}{l}\text { Unemployment rate } \\
\text { in the target market }{ }^{\mathrm{b}}\end{array}$ & $\begin{array}{l}\text { The unemployment rate expresses the } \\
\text { share of the labor force that is jobless in } \\
\text { percentage terms. }\end{array}$ & High & Low \\
\hline Industry position & $\begin{array}{l}\text { Industry position indicates how the } \\
\text { company's industry compares to foreign } \\
\text { competition. }\end{array}$ & Weak & \begin{tabular}{|l|} 
Strong \\
\end{tabular} \\
\hline
\end{tabular}

I had participants conduct example decisions as well as an understanding questionnaire that clearly indicated that only the upper and lower bounds of possible outcomes are diagnostic and decision relevant for the risky option (Investment A). Lastly, after each capital budgeting 
decision in the experiment, the participants in treatments with additional information cues were asked to indicate which cues they utilized for their decision. Upon completion of the questionnaire Appendix A - Part 2, the next decision round was automatically initiated.

\subsubsection{Compensation}

Participants were paid based on their investment outcome of one randomly selected decision period. The compensation was computed as follows:

Budget allocation in percent to Investment $A \times$ outcome of Investment $A+$ $(1-$ budget allocation in percent to Investment $A) \times$ outcome of Investment $B$ For participants assigned to the high-risk treatments, the range of possible outcomes for Investment A spanned from a minimum of 0 ECU to a maximum of 204,000 ECU. As the outcome of Investment A was randomly determined and could only assume either the lower or upper bound, Investment A had extremely high variance of returns. Unlike the high-risk treatments, the low-risk treatments faced a range of possible outcomes for Investment A, from a minimum of 43,000 ECU to a maximum of $161,000 \mathrm{ECU}$. Hence, Investment $\mathrm{A}$ in low-risk treatments was still risky, but with lower variance. The risk-free alternative, Investment B, exhibited the same NPV as Investment A. Strictly speaking, a rational investor would be indifferent in the budget allocation regarding the two investments. On average, the participants received $€ 10.1$ for their participation.

\section{$2.4 \quad$ Results}

\subsubsection{Dependent variables and descriptive statistics}

To test my hypotheses, I employ decision makers' investments as the first dependent variable in my statistical models. Specifically, I track the absolute amount of EC that decision makers allocate to Investment $\mathrm{A}$, the risky investment option. By definition, the variable ranges from 0 to 100,000 , where for 0 no budget is allocated to Investment A and for 100,000 all disposable budget is allocated to Investment A. I observe the individual investment choices of each 
participant across all six decision rounds. Table 5 presents descriptive statistics of the dependent variable for six experimental treatments. The means of the investment amounts indicate that high risk generates lower investments in Investment A. Moreover, I can show that an increasing number of nondiagnostic information cues decreases decision makers' investments.

\begin{tabular}{|c|c|c|c|c|c|c|}
\hline \multirow[b]{3}{*}{ Variables } & \multicolumn{4}{|c|}{$\begin{array}{c}\text { TABLE } 5 \\
\text { Descriptive Statistics } \\
\text { Dependent Variable Means } \\
\text { (Standard Deviations in Parentheses) }\end{array}$} & & \\
\hline & \multicolumn{3}{|c|}{ Low Uncertainty } & \multicolumn{3}{|c|}{ High Uncertainty } \\
\hline & o Cues & 6 Cues & 12 Cues & 0 Cues & 6 Cues & 12 Cues \\
\hline $\begin{array}{l}\text { Amount } \\
\text { invested in } \\
\text { Investment A }\end{array}$ & $\begin{array}{r}46366 \\
(24449.0)\end{array}$ & $\begin{array}{r}41606 \\
(28228.8)\end{array}$ & $\begin{array}{r}29767 \\
(26434.8)\end{array}$ & $\begin{array}{r}39271 \\
(30016.9)\end{array}$ & $\begin{array}{r}30967 \\
(24055.2)\end{array}$ & $\begin{array}{r}29067 \\
(27262.8)\end{array}$ \\
\hline $\mathrm{N}$ & 20 & 20 & 20 & 20 & 20 & 20 \\
\hline
\end{tabular}

Amount invested in Investment $A$ describes the exact amount of experimental currency that has been allocated by participants in each decision round to the risky investment option called Investment A

The second dependent variable of interest is the share of nonfinancial information used by decision makers. I observed how many nondiagnostic information cues were utilized to evaluate Investment $\mathrm{A}$ in the decision task. By definition, the variable ranges between 0 and 1 , depending on whether no financial information, only financial information or a combination of financial and nonfinancial information had been used by decision makers. Table 6 contains descriptive statistics of the total number of used information cues as well as the share of nonfinancial information used across treatment groups 3-6. I can observe that the number of cues used increases with an increasing number of nondiagnostic information available. A t-test analysis reveals that this difference is statistically significant $(\mathrm{t}(239)=-25.21, \mathrm{p}=0.01)$. 


\section{TABLE 6 \\ Descriptive Statistics \\ Dependent Variable Means \\ (Standard Deviations in Parentheses)}

\begin{tabular}{|c|c|c|c|c|}
\hline \multirow[b]{2}{*}{ Variables } & \multicolumn{2}{|c|}{ Low Risk } & \multicolumn{2}{|c|}{ High Risk } \\
\hline & 6 Cues & 12 Cues & 6 Cues & 12 Cues \\
\hline \multirow{2}{*}{$\begin{array}{l}\text { Total number of } \\
\text { information cues used }\end{array}$} & 1.71 & 3.15 & 1.71 & 3.24 \\
\hline & (1.09) & (1.88) & (1.11) & (2.10) \\
\hline \multirow{2}{*}{$\begin{array}{l}\text { Share of nonfinancial } \\
\text { information cues used }\end{array}$} & 0.59 & 0.40 & 0.45 & 0.49 \\
\hline & $(0.30)$ & $(0.25)$ & $(0.31)$ & $(0.28)$ \\
\hline $\mathrm{N}$ & 120 & 120 & 120 & 120 \\
\hline
\end{tabular}

Total number of information cues used describes the exact amount of non-diagnostic information cues that have been used by participants in our experiment in each decision round

Share of nonfinancial information cues used describes the ratio of nonfinancial information cues used by participants in our experiment compared to the total number of nondiagnostic information cues used

\subsubsection{Hypotheses tests}

To test the effect of risk and nondiagnostic information on capital budgeting behavior, I test the following model:

Amount invested in Investment $A=\alpha 0+\alpha 16$ Information Cues $+\alpha 212$ Information Cues +

$$
\alpha 3 \text { Level of Risk }+\varepsilon
$$

where $\alpha_{0}$ is the intercept and mean amount of EC invested in Investment A, given that all predictor variables are set to zero. 6 Information Cues and 12 Information Cues measure the amount of nondiagnostic information provided to decision makers. The variable $\alpha_{3}$ is the coefficient of a dummy variable that takes a value of 0 if participants were assigned to the lowrisk treatments, and a value of 1 if participants were assigned to one of the high-risk treatments. 
TABLE 7

OLS Regression Models

\begin{tabular}{|l|c|c|}
\hline & \multicolumn{2}{|c|}{$\begin{array}{c}\text { Dependent Variable: } \\
\text { Amount invested in Investment A }\end{array}$} \\
\hline Explanatory Variables & Model 1 & Model 2 \\
\hline 6 Information Cues & $-6532 *$ & -4760 \\
12 Information Cues & $-13402 * * *$ & $-16599 * * *$ \\
Level of Risk & $-6145 *$ & -7095 \\
Level of Risk * Information Cues & & -3544 \\
Level of Risk * 12 Information Cues & & 6395 \\
Constant & $45890 * * *$ & $46366 * * *$ \\
\hline Clustered & Experimental ID & Experimental ID \\
Number of Observations (N) & 720 & 720 \\
Adjusted R-squared & 0.0516 & 0.0572 \\
\hline
\end{tabular}

$*, * *, * * *$ significant at the $.10, .05$ and .01 levels, respectively.

6 Information Cues is a binary variable that describes the number of nondiagnostic information cues provided to participants in our experiment in each decision round that could be used for decision making purposes

12 Information Cues is a binary variable that describes the the number of nondiagnostic information cues provided to participants in our experiment in each decision round that could be used for decision making purposes

Level of Risk is a binary variable that describes whether the participant in our experiment has been exposed to a low risk decision context or a high risk decision context

To test Model 1, I included all participants' capital budgeting choices from all six decision rounds clustered by experimental ID number. Results are shown in Table 7. The results demonstrate that the coefficient of 6 Information Cues is negative and significant $\left(\alpha_{1}=-6532\right.$, p-value $<0.10)$. A provision of six nondiagnostic information cues in capital budgeting decisions is indeed associated with lower investments. For 12 Information Cues, my analysis shows a similar, statistically significant outcome $\left(\alpha_{2}=-13402\right.$, p-value $\left.<0.01\right)$. From these results, I can conclude that a provision of nondiagnostic information creates a dilution effect that generally reduces decision makers' investments, which supports hypothesis 1a. To determine whether the coefficients of the two variables are substantially different from one 
another, I conducted an F-test. I find that the coefficients are in fact statistically different from one another, with a probability of $92.46 \%$. Therefore, I can deduce that more nondiagnostic information amplifies the dilution effect such that decision makers invest less. This finding also supports my hypothesis $1 \mathrm{~b}$. Using the same model, the coefficient of Level of Risk is negative and significant $\left(\boldsymbol{\alpha}_{3}=-6145, \mathrm{p}\right.$-value $\left.<0.10\right)$. Hence, risk in capital budgeting decisions is indeed associated with a lower investment $(10,639 \mathrm{ECU}$ lower) than in a decision scenario with low risk.

To analyze how decision makers use nondiagnostic information in capital budgeting decisions and how their preferences for particular types of information unfold when confronted with risk and cognitive load, I specify the following model:

Share of nonfinancial information used $=\alpha 0+\alpha 112$ Information Cues $+\alpha 2$ Level of Risk + a3 12 Information Cues $\times$ Level of Risk $+\varepsilon$

where 12 Information Cues is a dummy variable that equals 1 for treatments with 12 cues of information and zero for treatments with 6 cues of information. Level of Risk is a dummy variable that equals 1 for treatments with high risk decision scenarios and zero otherwise. 12 Information Cues $x$ Level of Risk is the interaction variable of the two preceding variables. I run this model for the sample, excluding the treatments without information cues in addition to NPV as there is no nondiagnostic information available for participants to integrate in their decision process. Table 8 shows the OLS regression models for Model 2. 


\section{TABLE 8}

\section{Additional OLS Regression Models}

\begin{tabular}{|l|c|c|c|}
\hline & \multicolumn{3}{|c|}{ Dependent Variable: } \\
& \multicolumn{2}{|c|}{ Share of Nonfinancial Information Used } \\
\hline Explanatory Variables & Model 3 & Model 4 & Model 5 \\
\hline 12 Information Cues (IC) & $-0.076 * * *$ & $-0.076 * * *$ & $-0.191 * * *$ \\
Level of Risk & & -0.022 & $-0.138 * * *$ \\
Level of Risk * 12 IC & & & $0.232 * * *$ \\
Constant & $0.518 * * *$ & $0.529 * * *$ & $0.587 * * *$ \\
\hline Clustered & Exp. ID & Exp. ID & Exp. ID \\
Number of Observations (N) & 480 & 480 & 480 \\
Adjusted R-squared & 0.0144 & 0.0136 & 0.0502 \\
\hline
\end{tabular}

$*, * *, * * *$ significant at the $.10, .05$ and .01 levels, respectively.

12 Information Cues is a binary variable that describes the the number of nondiagnostic information cues provided to participants in our experiment in each decision round that could be used for decision making purposes

Level of Risk is a binary variable that describes whether the participant in our experiment has been exposed to a low risk decision context or a high risk decision context

In Model 3 the coefficient of 12 Information Cues is negative and significant $\left(\boldsymbol{\alpha}_{1}=-0.076\right.$, $\mathrm{p}=0.01)$. This result remains consistent in Model 4, in which I introduced Level of Risk. Hence, I can assert that an increasing number of nondiagnostic information cues or cognitive load reduces the share of nonfinancial information included in the capital budgeting decision process. The coefficient of Level of Risk in Model 4 is not statistically significant, however, when I integrated the interaction variable of 12 Information Cues and Level of Risk in Model 5, all independent variables become statistically significant. 12 Information Cues $\left(\alpha_{1}=-0.191\right.$, $\mathrm{p}=0.01$ ) remains to be statistically significant, although the coefficient increases, so that more nondiagnostic information drives decision makers to use almost $20 \%$ less nonfinancial 
information as compared to a scenario with less nondiagnostic information provided. Further, Level of Risk $\left(\boldsymbol{\alpha}_{2}=-0.138, \mathrm{p}=0.01\right)$ puts an additional cognitive strain on decision makers in a capital budgeting regime, so that the share of nonfinancial information used is lowered as well by $13.8 \%$. The interaction variable 12 Information Cues $x$ Level of Risk assumes a positive coefficient and is also significant at the .01 percent level $\left(\alpha_{3}=0.232, \mathrm{p}=0.01\right)$.

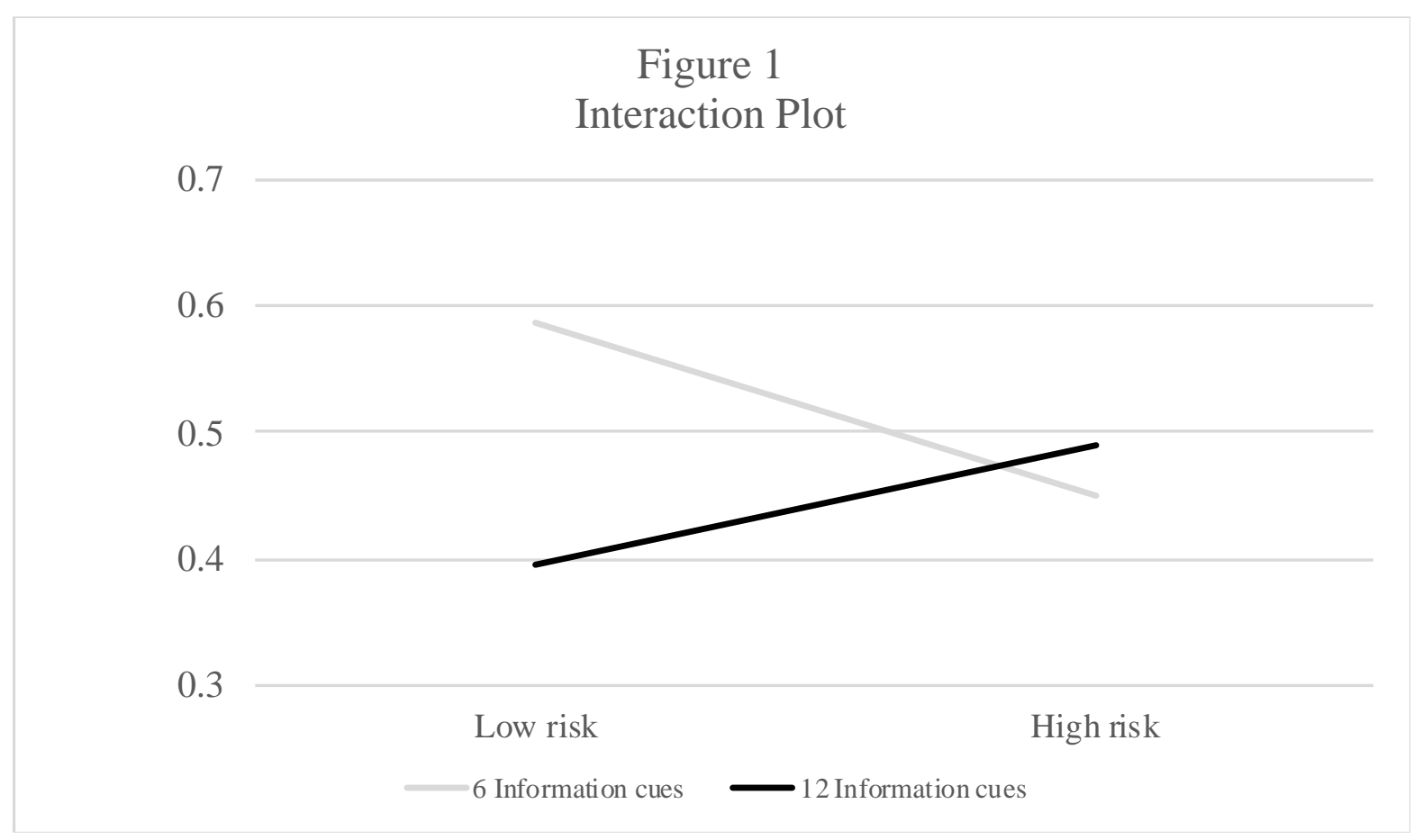

To scrutinize the interaction effect in more detail, the interaction plot is portrayed in figure 1. With relatively low amount of nondiagnostic information in a low risk decision scenario, decision makers integrate more nonfinancial information into their decision process. An observation that is in line with behavior suggested by accounting literature. However, when the amount of nondiagnostic information cues increases, ceteris paribus, the cognitive load reduces the share of nonfinancial information used because decision makers revert to financial cues instead. This effect is attributed to the degree of familiarity decision makers have with different types of information cues. Under cognitive load, decision makers prefer information that is familiar, in my experiment, this is financial information. Analyzing the degree of familiarity, I find that decision makers are significantly more familiar with financial information cues as 
compared to nonfinancial ones $(\mathrm{t}(239)=6.57, \mathrm{p}=0.01)$. In a high-risk decision context, regardless of how much nondiagnostic information is provided, decision makers converge towards an even share of financial and nonfinancial information cues. My result suggests that in high risk decision scenarios, where according to finance and accounting scholars the benefits of integrating nonfinancial information into the decision process are the highest, decision makers tend to view different types of information indifferently. Hence, I can confirm $\mathrm{H} 2$ that decision makers use more nonfinancial information only when risk and cognitive load is relatively low.

\subsection{Discussion and conclusion}

My study investigates the dilution effect caused by nondiagnostic information in capital budgeting decisions. Moreover, I examine the influence of risk and cognitive load decision makers' capital budgeting behavior, particularly their preferences in different types of information. Although my experiment is chiefly concerned with the ramifications of additional nondiagnostic information in capital budgeting, my findings also contribute to the ongoing discourse about the role of financial and nonfinancial measures in these types of decisions. Hence, I also explore the question of whether nonfinancial financial information is really used by decision makers, especially in situations where risk and cognitive load prevails.

My results show that nondiagnostic information creates a dilution effect in capital budgeting decisions such that decision makers reduce investments. I find this effect to be more pronounced as more nondiagnostic information is provided. My results also show that decision makers exposed to high risk invest significantly less as compared to their peers in a low-risk setting. Furthermore, I find decision makers to use more nonfinancial information in their decision processes in the absence of risk and cognitive load. This is in line with general advocacy in accounting literature, to compliment capital budgeting decisions with nonfinancial information to form a more profound decision fundament. However, decision makers behavior changes 
when exposed to high cognitive load, which leads to a reduction of nonfinancial information, such that more familiar financial information is used. In the light of high risk, decision makers show indifferent behavior towards financial and nonfinancial information.

My study helps to address the scarcity of research in the area of capital budgeting behavior. First, my study adds to a growing stream of literature on the use of information and provides evidence that more information is not necessarily better (Shanteau 1992; Waller and Zimbelman 2003; Eppler and Mengis 2004; McKinsey Global Institute 2018). More nondiagnostic information amplifies suboptimal capital budgeting behavior. Rather than providing large amounts of information to decision makers, irrespective of its helpfulness, I advocate limiting the amount of information. The significance of this suggestion has never been as important as today because the sheer amount of information has substantially increased over the last decade and technological information systems continue to decrease the costs of information that can be provided to managers (Brown-Liburd et al. 2015; McKinsey Global Institute 2018). Second, I provide evidence of a dilution effect in capital budgeting decisions due to an overload of information that encourages suboptimal decision making. This outcome underlines the importance of providing information that is specifically diagnostic to managers in capital budgeting decisions, rather than providing a large set of information that is nondiagnostic. Third, although I issued only nondiagnostic information to decision makers in my experiment, I could observe varying preferences towards different types of information depending on the decision context. I showed that more nonfinancial information was only used in the absence of cognitive load and risk. With an increase in cognitive load, decision makers reverted to familiar financial information, while high risk made decision makers indifferent towards different types of information. This finding is particularly important because (1) it stands in stark contrast to general advocacy of accounting literature to integrate more nonfinancial information into decision processes when risk is high (Sundem 1975; Myers 1984; 
Ross 1995; Verbeeten 2006; Chen 2008) and (2) cognitive load originating from the amount of information drives decision makers to overemphasize more familiar information, which may be suboptimal for the decision process (Tversky and Kahneman,1973; 1974; Whitney et al., 2008; Gerhardt et al., 2013; Benjamin et al., 2013).

Besides the above contributions, my results also have direct managerial implications. In particular, my findings can help to design information systems in capital budgeting. It is not only the amount of information that is relevant and should be taken into account by firms, but also the type of information, depending on the level of risk and cognitive load in certain settings. As such, I can provide guidance on how to structure and improve the process of capital budgeting where the actual decision of investing is at the core.

Like any other scholarly work, this study is subject to some limitations that could stimulate future research. First, I have conducted a laboratory experiment, which is, by definition, a simplification of a real-world situation. Hence, field research with corporate managers facing a similar scenario could make a valuable contribution. Such research would also provide an opportunity to observe different levels of investment experience, as managers may or may not have encountered certain corporate capital budgeting decisions. Second, I issued the additional nondiagnostic information to the participants in the form of an unstructured overview to preclude perception biases. Yet some research has shown that the presentation of information, particularly measures, can be of importance for the observer, as discussed by Cardinaels and van Veen-Dirks (2010). Subsequent research could investigate how the presentation of nondiagnostic information affects the decision setting examined in my study. Third, I provided nondiagnostic information only, which means that my results concerning decision makers' preferences of different information types under distinct circumstances would also need to be validated on its robustness using settings with diagnostic information. 
Finally, I have merely conducted a first examination of how capital budgeting decisions are affected in light of nondiagnostic information and risk. I believe that there are other factors besides these two aspects that can influence managers' capital budgeting behavior under the defined circumstances. Hence, it is desirable to pursue scholarly work to foster a more concise understanding of strategies that can alleviate the dilution effect in capital budgeting decisions. 
3. An empirical study on the role of top management support in intrapreneurship 


\begin{abstract}
Intrapreneurship is an integral strategic approach of large corporations to access additional profit pools through new venture creation. The purpose of this study is to investigate the role of top management in intrapreneurship and shed light on the conducive ramifications for intrapreneurship from creating an intrapreneurial environment in an established organization. I provide theoretical explanations enlarged by evidence from case studies to develop a management questionnaire for intrapreneurs. The empirical survey data delineates the relationship between top management support (TMS) and intrapreneurship as well as the mediation effect on that relationship stemming from characteristics of intrapreneurial environment. In line with my expectations, I find that TMS has a positive influence on intrapreneurship project success, while its impact on intrapreneurship project innovativeness is arguably negative. As I hypothesized, some characteristics of intrapreneurial environment are particularly beneficial for project innovativeness. My results also confirm that an intrapreneur's internal company network positively mediates the relationship between TMS and project innovativeness.
\end{abstract}




\subsection{Introduction}

It has long been recognized that intrapreneurship, or corporate entrepreneurship, has generated substantial successes in creating product innovation and profit growth for established corporations (Ireland et al., 2006a, b; Morris et al., 2010). While Pinchot (1985) defines intrapreneurship strictly as the practice of developing novel ventures within an existing organization, to exploit a new opportunity and create economic value, Antoncic \& Hisrich (2003) view intrapreneurship less constrained, but just as appropriate, as the behaviors that are related to the departures from customary ways of doing business in existing organizations. Due to shortening company lifespans, there has been a growing interest in the use of intrapreneurship as a means for corporations to facilitate innovative activities of their employees and, at the same time, enhance corporate performance through the implementation of new business ventures (Cooper, 1998; Deloitte, 2015; Innosight, 2018). However, the establishment of successful intrapreneurship in corporations is difficult, because intrapreneurial activity is a bottom-up initiative that challenges fundamental principles of mature organizations. While some researchers in management accounting have already captured valuable understanding on the creative processes fostering in particular the initiation of intrapreneurship projects (Grabner, 2007; Brüggen, Feichter \& Williamson, 2017), the comprehensiveness of intrapreneurship is not yet established. The importance of intrapreneurship requires the allocation of further management accounting research efforts to understand the underlying mechanisms driving intrapreneurship in order to facilitate the design of management control systems for intrapreneurs and intrapreneurial behavior. The purpose of this paper is to investigate the role of top management in intrapreneurship and understand the conducive ramifications for intrapreneurship from creating an intrapreneurial environment in an established organization. 
Using a mixed method approach ${ }^{3}$, this study sets out to bring together management accounting and intrapreneurship literature to analyze how companies facilitate intrapreneurship projects. An intrapreneur is generally confronted with balancing working time between daily work routines and intrapreneurial activities. While structural flexibility in smaller firms grants intrapreneurs to grapple with entrepreneurial initiatives, process-oriented structures in large firms restrict employees' time resources for activities outside their predefined work tasks (Burgelmann, 1984; Kuratko et al. 1990; Carrier, 1994; Antoncic \& Hisrich, 2001; Bamber et al. 2002). Facilitating effective intrapreneurship is therefore contingent upon the top management team's ability to balance between conventional business with near-term objectives, so-called exploitation, and new business ventures with long-term objectives, socalled exploration (Smith \& Tushman, 2005). Similarly, corporate hierarchy inhibits intrapreneurs' work discretion. In particular, decision-making competencies are usually centralized, such that decision processes require long lead times and substantial efforts for preparation (Dean \& Sharfman, 1996; Papadakis et al., 1998; Lyon et al., 2000). intrapreneurship, however, is reliant upon a high degree of decision autonomy to facilitate decentralized decision-making for those who carry out intrapreneurial undertakings (Kuratko et al., 1990; Antoncic \& Hisrich, 2001; Alpkan et al., 2010), a condition that is commonly scarce in large corporations. To pursue intrapreneurship, intrapreneurs seek to collaborate across department boundaries to attain an interdisciplinary network of experts for their initiatives (Peters and Waterman 1982; Pinchot 1985; Zahra 1991; Adler \& Chen, 2011). Such an approach is scarcely endorsed by functional matrix structures prevalent in established corporations to date. While intrapreneurs challenge the status quo to create new ventures or

\footnotetext{
${ }^{3}$ This study contributes twofold. First, I conducted 10 structured interviews with corporate managers from different industries responsible for intrapreneurship (programs) in their respective companies. The synthesis of these interviews provides comprehensive insights of top management support as well as drivers of an effective corporate intrapreneurial environment. Second, I surveyed 63 intrapreneurs in a multinational corporation to probe whether top management support can induce an intrapreneurial environment that influences intrapreneurial project success.
} 
product innovations, corporations tend to sustain the status quo by means of a so-called corporate immune system (Sykes, 1984; Birkinshaw \& Ridderstråle, 1999).

Research by Hornsby et al. (2009) suggests that with an increasing managerial level these structural deficiencies can be alleviated to implement more entrepreneurial ideas. While these results indicate that top management support (TMS) may be beneficial to intrapreneurs, previous studies have also found that what begins as support can turn into disturbance (Millson et al., 1992), particularly so, when projects require deep technological understanding (Ettlie et al., 1984; Takeuchi \& Nonaka, 1986). Research by Dess et al. (2003) and Phan et al. (2009) underlines that there is still an important need to demonstrate how firms build effective structures and processes to foster intrapreneurship.

In the management accounting literature the role of top managers has only been thoroughly investigated in new product development (Davila, 2000; Bisbe \& Otley, 2004; Davila et al., 2009; Jørgensen \& Messner, 2010; Bedford, 2015). These studies demonstrate that management involvement along a structured process can have positive ramifications. For more iterative, creative and bottom-up driven processes as for intrapreneurship projects, this question remains unanswered.

My study considers TMS not only a prerequisite for intrapreneurship, but also an antecedent for intrapreneurial environment, which in itself, is a key factor of successful intrapreneurship. Unlike prior studies focusing on systematic product development projects, the unit of analysis in my study is the intrapreneurship project itself. While TMS has been widely researched for formalized product development, my work describes the role of TMS for iterative and bottomup driven intrapreneurial projects. Further, this work contributes new evidence to the unsettled discussion of how TMS can create an intrapreneurial environment that drives the success of intrapreneurship. Lastly, my study attempts to prevent confounding effects that could stem from 
varying characteristics on firm level. This is why only data from large multinational corporations (MNC) have been collected for the purpose of this study.

The next part of this paper reviews previous research on the role of top management support in intrapreneurship and presents the underlying theoretical frameworks of the study. Section 3 depicts intrapreneurship through the lens of four representative case studies from large corporations. These cases delineate the variables of the study as well as the hypotheses. The following section develops the hypotheses for the empirical test based upon theory as well as case findings. Section 5 illustrates the research design for the survey. The last two sections discuss the results of the study and conclude with future research propositions.

\subsection{Theory development}

\subsubsection{Intrapreneurship}

The objective of intrapreneurship is to enable employees in large organizations to translate novel business ideas into an operational product, service or process that contributes to overall firm performance (Dess \& Lumpkin, 2005). The process of intrapreneurship is bottom-up and projects advance based on a hypothesis-driven approach and concretize over time through experimental validation of the latter. Due to the rather explorative nature, it is possible that the final product or service deviates from the initial idea, which is why intrapreneurship projects require particular top management attention and safeguarding to evolve. For this reason, prior research proposes management involvement across the different stages of an intrapreneurship project (Burgelman, 1983; Gilbert \& Bower, 2002).

First, managers need to impose strategic constituents, while allowing autonomous entrepreneurial initiatives at the operational level to happen. Second, an experimentation-andselection approach has to be facilitated to enable decentralized decision-making on the project level. This step in particular requires the activation of middle level managers. Third, top managers must recognize the strategic relevance of intrapreneurial activities to disseminate 
legitimization of these undertakings firm-wide. Fourth, it is the task of top management to be concerned about the pace and magnitude of change inflicted on the organization through the projects rather than the actual content. Lastly, new managerial approaches are necessary to facilitate collaboration between intrapreneurs and the organization in which they work. Although described as linear, this process is iterative and distinct from institutionalized new product development (NPD) processes. Therefore, continuous, but primarily situation-based, TMS is expedient in intrapreneurship.

\subsubsection{Top management support and intrapreneurial environment}

Prior studies on the role of top management explore goal specificity, project dedication and resource allocation in new product development (NPD) particularly (Cooper, 1988; Pinto et al., 1993; Swink, 2000). Empirical research finds that TMS and resource commitment relates to successful NPD, while the lack thereof has adverse effects (Swink, 2000). Furthermore, there is consensus in the academic discourse that inadequate leadership has detrimental ramifications on NPD initiatives (Swink, 2000). Zirger and Maidique (1990) find that TMS attracts ambitious talent across functional domains within an organization. A high level of top-down management commitment draws in development personnel that assumes NPD project ownership and becomes more willing to take risks. In addition, dedicated TMS creates enthusiasm among project participants catering to persistent goal achievement. Research by Swink et al. (1996) alludes to the importance of involved top managers in NPD as they have the ability to attain resources for unanticipated project expenditures.

Although there is general consensus on the beneficial nature of TMS, other perspectives have raised the question of whether TMS is always contributing to NPD project success. Gersick et al. (1990) state that TMS can turn into controlling, even interference, of the project management. This effect appears to be more severe the higher the technological advancement is within a project (Takeuchi \& Nonaka, 1986; Swink, 2000). Under those circumstances, 
scholars have suggested that deep technological understanding and experience in managing innovative projects take the place of TMS as key determinants of NPD success (Song \& Montoya-Weiss, 1998).

While the impact of TMS on NPD projects is well established in the existing literature, scholarly work that links TMS with rather creative and iterative intrapreneurship proceedings is still scarce. A number of studies have investigated the relationship between organizational support and intrapreneurial project success (Antoncic, 2001; Antoncic, 2007; Rutherford \& Holt, 2007; Alpkan et al., 2010). The organizational support construct is multifaceted and integrates different organizational antecedents such as management support, time and resource availability, work discretion and loose intra-organizational boundaries (Antoncic \& Hisrich, 2001; Hornsby et al., 2003; Hayton, 2005). Recent studies have acknowledged the confounding effects of the construct and began to model antecedents distinctly to gain a more granular understanding of intrapreneurship (Hornsby et al., 2002; Antoncic \& Zorn, 2004; Holt \& Rutherford, 2007; Alpkan et al., 2010).

TMS is essential for generating new projects and awaking entrepreneurial spirit within an organization (Kuratko and Montagno 1989). The essence of effective performance under entrepreneurial spirit is concerned with employees' ability to manage uncertainty and to deal with different circumstances and boundaries with degree of their personal expertise (Schuler 1986). TMS in this situation is the problem solving and conflict resolution ingredient in the intrapreneurial undertaking. It is required in the idea generation, development, and particularly implementation stages of the ideas (Burgelman, 1983).

Time availability is the sufficiency of time resources to work on creating new ideas and implementing novel business ventures (Brazeal, 1993; Schuler, 1986; Kuratko et al., 1990). Although some ambitious intrapreneurs pursue their intrapreneurial initiatives in their spare time (Van den Ende et al., 2003), time availability for personnel is a crucial determinant for 
both an intrapreneur's day-to-day work as well as intrapreneurial ideation, for example, to experiment and develop (e.g. Pinchot, 1985; Fry, 1987). Provision of designated time resources encourages employees to dwell on new business ventures with the result of putting their ideas into action (Sundbo 1999; Hornsby et al., 2002).

Another factor of an intrapreneurial environment is decision autonomy within the organizational structure, especially work discretion for employees. An effective intrapreneurial environment encompasses top management that encourages decentralized decision-making as an element of corporate strategy (Mintzberg, 1973; Khandwalla, 1973; Slevin \& Covin, 1990; Covin \& Slevin, 1989; Barringer \& Bluedorn, 1999). Decision autonomy empowers employees to steer their projects independently (Lober, 1998; Kuratko et al., 1992; Hornsby et al., 2002) and implement novel ideas to seize business opportunities (Lumpkin \& Dess, 1996; 2001). Autonomy extends to an employees' degree of initiative upon their formal work and implementing improvement efforts or resolving problems (Tatikonda \& Rosenthal, 2000). Autonomous employees or managers can think, act, and afford to risk more for innovative consequences, and they can afford to allow others' freedom.

Creative work paired with the opportunity to collaborate cross-functionally is yet another driver of innovative initiative in firms (Gapp \& Fisher, 2007). Where well-trained, diverse teams are proactively encouraged to work together innovative outcomes can be increased (Bantel \& Jackson, 1989; Alpkan et al., 2010). As for intrapreneurship, intrapreneurs require the collaboration to conceive innovative concepts in early ideation, while also needing different competencies to creating complex novel business offerings, or even entirely new ventures. Enabling collaboration across department borders, even firm borders, is in top managers range of influence. Again, intrapreneurship challenges fundamental structural antecedents of established organizations, which are commonly managed in matrix or even silo structures and naturally inhibit interdisciplinary cooperation. 
As prior literature shows, scholarly research to date offers a variety of different determinants of intrapreneurship success. It is not clear what factors are determinants for intrapreneurial success. Prior studies do not define a no consistent set of antecedents that isolates the key drivers of intrapreneurship projects. The reasons for this lack of consistency can be dissected into two constituents. First, scholars view intrapreneurship as a means to generate a particular outcome that positively contributes to firm performance. However, it is inconsistent, if not undefined, what the potential outcomes of intrapreneurial activity ought to be. While some researchers' interest is on rather intangible dimensions such as entrepreneurial mindset or proactiveness of employees, others focus on more tangible outcomes, for example, new ventures or new patents. Second, until today, scholarly work has strongly cultivated debates on a theoretical level mainly revising or reiterating theoretical fundament in the space of intrapreneurship, while neglecting the step of revisiting practitioners and reevaluating the current intrapreneurship efforts in practice. It is for that reason, I set out to contribute more clarity in this respect to the academic literature by going to the field. As a means to acquire indepth practical knowledge, case studies provide invaluable insights into the mechanism behind intrapreneurship and reveal the actual success drivers that make intrapreneurship work in established corporations.

\subsection{Case Studies}

To understand how corporate managers structure intrapreneurship (programs), I identified the 250 largest companies in Europe by the number of employees. Applying a systematic web research, I was able to identify firms that officially announced their intrapreneurship activities. From that, I backtracked contact information of the individuals in charge of intrapreneurship in the respective organizations. Of all inquired individuals, I received the opportunity to speak to 10 MNCs from four different countries across Europe. I interviewed the manager responsible for planning, implementing and overseeing the company's intrapreneurial activities. To extend 
the still scarce literature on TMS in intrapreneurship, I decided to follow an exploratory approach by using case studies to build knowledge about this phenomenon. Interviews were guided by 18 questions focused on the formal system and the intrapreneurial initiatives themselves. All questions were open-ended, this gave me the opportunity to adjust depending on the configuration of the company's intrapreneurial approach without losing direction overall. Appendix B shows the interview questionnaire. I selected four of the ten case studies conducted. This helped me to reduce overlap as well as redundancies in the managers' responses while providing a wide variance in perspectives from the different interviewees. Hereafter, I describe the cases on the diversity of intrapreneurship and the characteristics of TMS.

\section{Manager A}

Manager A worked for a large manufacturing company in Northern Europe. For the company's intrapreneurial activities, the manager had built an entire department solely dedicated to the company's intrapreneurs. The manager was still in charge of operating the day to day work, which mainly encompassed "bringing people together to make collaboration and innovation happen". The main objective of the program was to enable any employee to become an intrapreneur and to find support to develop a solution for a particular customer problem that has been detected through daily work and/or from private observations. In the initial stage of the project, the manager mainly focused on sparing with the intrapreneurs as this process would determine whether or not someone was serious about their initiative or not. There was no fixed project duration as each intrapreneur would work "at his/her own pace, just like anywhere else in working life".

As projects exceled, the manager ensured that a committee of sponsors would be made aware of these projects. The committee consisted of key top managers from R\&D, Production, Business Development as well as Sales \& Marketing. On a quarterly basis this committee would come together to assess projects on two criteria, whether the project had the potential for a 
significant contribution to the firm's bottom line and if it had a strategic fit. According to the manager "some very creative projects with great potential were not pursued as it was unclear how they would integrate into corporate strategy". Up to this point, the intrapreneur would work on the project alongside daily work tasks. The reason for that was to "demonstrate personal commitment". Given a positive decision outcome from the committee of sponsors, an intrapreneur would be granted a 5-digit budget to continue working on the project, while receiving access to methodological and collaboration opportunities from the internal intrapreneurship department. The budget would be under full discretion of the intrapreneur and could be invested as the intrapreneur saw fit. The main goal at this stage was to "iterate towards a clearly identifiable customer problem". Intrapreneurs would also be permitted to use twenty percent of working time or 1 day a week for their respective projects.

In case the business proposal showed traction and customers were fond of the proposed product or service, intrapreneurs were once more invited to present their project in front of the committee; all other projects were terminated. If the committee could be convinced by the preliminary results, the project was implemented. Along with great management attention, intrapreneurs' reward would consist of two elements. First, the manager would be preferred for internal promotion or, if required, manage the business area that originated from the intrapreneurship project altogether. Second, the manager would get the opportunity to present the project in front of an audience of interested colleagues and serve as mentor for other intrapreneurs. This was considered an important incentive for intrapreneurship in that firm.

\section{Manager B}

Manager B had built an intrapreneurship program for an international telecommunications company. The program was supported by a board member responsible for HR, innovation and organizational development. At the time of the interview, the program had already been running 
for 6 years and the manager had been in charge throughout that time, which gave me access to a great deal of experience in intrapreneurship.

The key objective of the program was to "build business ventures that secure a profitable share in new markets for the firm and that are so-called investable". Hence, intrapreneurs had to create a project roadmap with concrete milestones and a budget that a decision committee could invest in. To accomplish this, the program was divided into two phases, an exploration and execution stage. The exploration stage was fulltime and lasted 3 months. To get in, potential candidates needed to convince a jury consisting of managers running the intrapreneurship program as well as outside entrepreneurs and experts. During those 3 months, intrapreneurs were coached oneon-one by experienced entrepreneurs from outside the organization and collectively received training in project management, business modeling as well as design thinking. "The goal is to equip our intrapreneurs with the necessary skill-set to concretize the business idea." Once the exploration stage was completed, intrapreneurs present their ventures to a decision committee of top managers including the sponsoring board member. Based on the committee's assessment, the project was either terminated or equipped with significant funding to proceed to the 6-12 months execution stage. Upon entering the execution stage, intrapreneurs had the opportunity to showcase their ventures at an internal fair to recruit colleagues to join their undertaking fulltime and/or span a network of supporters in the organization. Top management empowered the intrapreneurs such that crucial decisions on the project could be taken freely by the intrapreneurs themselves. For instance, "it is up to any intrapreneur's discretion on where to locate the project team or how to allocate the project budget". Following the execution stage, intrapreneurs were asked to provide evidence on the viability of the business and the "investable proposal" for the decision committee to determine how to proceed with the project. Two possible options existed. Either the project was terminated and the intrapreneur went back to his former corporate position or the project was transferred into a new entity within the 
organization and the intrapreneur assumed responsibility over the business. This was highly important, as from the experience gained in the program, it was clear to the manager that decoupling intrapreneurs from their projects at a rather early stage would likely result in project failure as one would lose the returns of the "sweat and tears" an intrapreneur had already invested into the project.

\section{Manager $C$}

Manager $\mathrm{C}$ had been overseeing the intrapreneurship program of an automotive company for more than 8 consecutive years. The program's objective was to fund intrapreneurs to build innovative, high-growth businesses that could create a positive impact for the firm on two levels, top-line contribution and build-up of new expertise. Sponsorship of the program was held by different stakeholders, represented in the program's core team, which counted five members and consisted of an innovation expert, a program expert, a controlling expert, an experienced company manager as well as a representative from the works council. The latter two were also part of the 15 people decision committee. According to Manager $\mathrm{C}$, the size of the committee did not reduce speed of decision-making for two reasons, (1) the committee days were fixed in everyone's calendar and (2) if someone was unable to attend, decisions were taken regardless. The committee comprised additional works council representatives and a member of the board of management; while its task was to continuously assesses the intrapreneurship projects for the duration of the program. "As a result of the numerous supporters, the program enjoys substantial visibility within the organization and draws curious attention from potential intrapreneurs." The full length of the program was made up of 7 stages: idea submission, idea pre-selection, idea pitch, incubator phase, business pitch, accelerator phase and final evaluation. Anyone within the organization could submit project ideas to the intrapreneurship program through the company's intranet. Naturally, the submitted project ideas exhibit a wide degree of innovativeness spanning from minor process optimizations over new product developments to 
completely new venture opportunities, therefore, a pre-selection by the program's core team determined projects' eligibility and potential before proceeding to the project idea pitch. Other submissions were declined. For preparing the idea pitch, candidates received access to a resource database with valuable content and inspiration that was meant to guide the development of their own pitch document. The idea pitch took place on a quarterly basis in front of the decision committee and usually encompassed 10-20 project proposals. Every member of the committee had equal voting rights and the vote was issued anonymously using a mobile application after every pitch presentation. The most compelling ideas based on a 5categorical decision logic entered the incubator phase. During the incubator phase, intrapreneurs were mentored and trained in groups using different workshop formats next to their regular day jobs over a period of three months. The aim was to develop a comprehensive business plan to be presented in front of the decision committee for project funding. All candidates of the incubator showcased their projects in the business pitch and requested an investment for their initiative. The selection criteria at this point were mainly based on “managers' experience, customer insights and hard numbers". Hence, only a small number of projects proceeded to the 6-12 months fulltime accelerator phase. The fulltime accelerator phase was meant to provide sufficient time for the intrapreneurs to develop their product, interact with customers and, ideally, converge towards product-market fit. Depending on the product development time, this project's time horizon could also be extended. Participants of the accelerator phase were able to recruit particular talent internally using the company's intranet or use part of their budget to hire consultants with relevant skillset to support their projects. Intrapreneurs were fully responsible for the project during the accelerator phase including budgetary decision and project management. The outcomes of the accelerator phase were presented to members of the board of management to display the product/service, milestone accomplishments and evidence on product-market fit. At this point, the program ended and it 
was determined, whether the intrapreneurial projects were "integrated into a company department, became a corporate spin-off or were discontinued". The intrapreneur's role usually remained linked to the project with varying degree of responsibility.

\section{Manager D}

Manager D was a business unit board member and also the head of the corporate intrapreneurship program. The program had been in place for approximately 2 years with the objective to create new revenue streams and explore strategically relevant topics. Strategic fields were as such predefined by the program manager in collaboration with senior management. According to manager D, intrapreneurial activities within the program had great board attention mainly attributed to the close personal connection that manager D shared with the CEO. This state of affairs would also come in handy whenever intrapreneurs would need to circumvent internal process operations to advance their projects. The format of the program appeared to be rather dynamic, yet I could identify two key stage gates; one being the entry gate at the start and the "top management marketplace" at the end of the program. To enter the fulltime program, project submissions were evaluated by a small team of 5 people including manager $\mathrm{D}$ and the assessment was based on an internally developed criteria catalogue. However, it was important to ensure that the projects could satisfy the expectations of top managers. This meant that projects tended to capture incremental innovation because this would have a more immediate benefit for top managers as compared to rather disruptive innovations that have a longer time horizon. Each project that entered the program received "sufficient funding" and access to a variety of support functions such as training material, dedicated HR and IT resources as well as mentors. During this phase, the intrapreneurs would work on their own discretion, however, budget decision needed confirmation from manager $\mathrm{D}$ as this was required by internal revision guidelines. In terms of collaboration, all intrapreneurs were motivated to convince colleagues to join their projects. Nonetheless, this was usually difficult 
according to manager $\mathrm{D}$ as other employees would not be relieved of their day jobs and because there was no platform for intrapreneurs to network outside their department or business unit. On a half year basis, the top management marketplace took place where "mature projects" were presented to a group-wide community of top managers. The goal of this stage gate was to find sponsors that would either continue financing the projects or even integrate an intrapreneurial project into their departments.

\section{Discussion of case studies}

Table 1 provides information on the respective understanding of project success and innovativeness based on the experience of intrapreneurship program managers in large corporations across Europe. Further, table 1 contains consolidated findings on the essential drivers of successful intrapreneurial initiatives as well as their manifestations within the corporations that participated in the case studies.

\section{TABLE 1}

Summary of the case studies

\begin{tabular}{|c|c|c|c|c|}
\hline & Manager A & Manager B & Manager C & Manager D \\
\hline $\begin{array}{l}\text { Top } \\
\text { Management } \\
\text { Support (TMS) }\end{array}$ & $\begin{array}{c}\text { Sponsorship by top } \\
\text { management from } \\
\text { different business areas }\end{array}$ & $\begin{array}{c}\text { Active supportby } \\
\text { dedicated member of the } \\
\text { board }\end{array}$ & $\begin{array}{l}\text { Active support by a } \\
\text { member of the board } \\
\text { and works council } \\
\text { representatives }\end{array}$ & $\begin{array}{l}\text { Sponsorship by } \\
\text { dedicated business unit } \\
\text { board member }\end{array}$ \\
\hline $\begin{array}{l}\text { Project } \\
\text { Innovativeness }\end{array}$ & $\begin{array}{l}\text { Only constrained by } \\
\text { strategic fit analyses }\end{array}$ & $\begin{array}{c}\text { Unlimited } \\
\text { No defined restrictions } \\
\text { for degree of } \\
\text { innovativeness }\end{array}$ & $\begin{array}{l}\text { Close to the core } \\
\text { Proximity to core } \\
\text { business as decision } \\
\text { criteria limited } \\
\text { innovativeness }\end{array}$ & $\begin{array}{c}\text { Incremental } \\
\text { Top managers would } \\
\text { seek to back projects } \\
\text { with immediate pay-off, } \\
\text { so very limited } \\
\text { innovativeness }\end{array}$ \\
\hline $\begin{array}{l}\text { Time } \\
\text { Availability }\end{array}$ & Low & High & Medium & High \\
\hline $\begin{array}{l}\text { Decision } \\
\text { Autonomy }\end{array}$ & High & High & High & Medium \\
\hline $\begin{array}{l}\text { Interdisciplinary } \\
\text { collaboration }\end{array}$ & Medium & High & High & Low \\
\hline
\end{tabular}


The case studies vividly show that managers are confident in intrapreneurship being the right tool to deliver innovation secluded from the core business. What varies, is the degree of innovativeness. While some managers expose strategic guidelines or proximity to the core business on their intrapreneurs, others only set the target on a profitability and a contribution to the organization's bottom line. Although some of the programs follow a basic step-wise logic, the activities within the steps are meant to be iterative and under discretion of the intrapreneurs. All managers confirm that intrapreneurship undertakings are always initiated bottom-up, which clearly distinguishes intrapreneurship from their structured counterparts in innovation management or NPD.

General consensus also resonates on the topic of TMS. Not a single intrapreneurship program is without the attention of the board of management, either through their involvement in the decision committee or as mentor for intrapreneurs. Manager D makes the case that under circumstances, it may even be required for intrapreneurship projects to have the support of top management because without some initiatives could not excel facing the internal process of a large corporation. Without the support of top management many initiatives could not even be launched if these were not sponsored and backed by individual or multiple top managers. This concerns not only highly innovative projects but any project that is somewhat outside of the daily work routine. Hence, based on the case studies I can delineate a causal relationship that TMS is an antecedent of intrapreneurship. Similar anecdotal evidence has also been provided by the other managers that see TMS to have positive ramifications on organizational inertia and resistance as well as speeding up or side-tracking "process clutter".

A recurring theme in every case study is time availability, which goes hand in hand with access to resources. Managers explain that these two elements are closely linked to the structure of the respective programs and thereby to the maturity level of the intrapreneurship project. Although Manager A synthetically creates a lack of time availability to challenge intrapreneurs and 
"separate the wheat from the chaff", it is depicted that with a lack of time, intrapreneurs cannot effectively pursue their initiatives and it would further hamper with the credibility of the intrapreneurship program. Moreover, the case studies reveal that most intrapreneurs are subject to some extent of decision autonomy. In most cases intrapreneurs can independently decide upon the use of their budget, some may even choose the place of work as long as it serves the intrapreneurship project. This autonomy is deemed necessary by the interviewed managers to foster intrapreneurs' motivation, while at same time let the "best informed person in the room take the decision". Lastly, collaboration or interdisciplinary exchange is a recurring element. Managers seek great value in the utilization of different skillsets to drive intrapreneurial projects forward. Manager B even goes that far to conduct special events for intrapreneurs to showcase their projects and attract talent from the core organization in pursuit of their ideas. In the words of Manager B, "a single person rarely has all the necessary competencies that are required beyond the ideation phase".

\subsection{Development of research hypotheses}

Based on the case studies, I could identify the three key drivers of successful intrapreneurship according to intrapreneurship program managers from large European corporations. The interview managers determined time availability, decision autonomy and internal network to be positively impactful on intrapreneurship. Building on these newly gained insights, I set out to understand the role of top managers to facilitate intrapreneurial activity. The responsibility of top management to foster successful intrapreneurship can be divided into two perspectives. For one, top managers in their capacity have the influence to reshape organizational structures to allow and alleviate intrapreneurial activity, and for the other, top managers can affect intrapreneurs' behavior on an individual level.

According to Young \& Jordan (2008), top management support is an important success factor for any project within an organization. Other studies indicate that projects, which are under the 
supervision of top managers tend to have higher chances of success in comparison to projects that are not (Pinto \& Slevin, 1987; Sumner, 1999; Belout \& Gauvreau, 2004). This is attributed to the general strategic importance that top managers' attention can lend to a particular initiative, but also top managers' personal and budgetary resources that are committed to the project to review planning, follow up on results and garner CEO sponsorship. Swink, Sandvig \& Mabert (1996) relate their findings to particularly innovative projects and show the importance of top managers to acquire additional budget for unanticipated resource requirements. Another side benefit of top management supported innovation projects is that development personnel is encouraged to join as they understand their involvement in these projects to offer them personal growth opportunities (Swink, 2000).

Intrapreneurial projects differentiate themselves from other projects in the sense that they are mostly driven bottom-up and can therefore be wrongfully understood by internal stakeholders as strategically irrelevant. According to Morton's (1983) case study research on project management, top managers as project champions have the ability to resolve stakeholder disagreement. Their authority allows top managers to mobilize opinion leaders in order to build general organizational support for the project from different stakeholders. Beyond that, it is in their realm to convince other top managers to also foster a positive mindset towards the intrapreneurship project, or even make it a priority on their agenda as well.

On the individual level, top management support manifests through motivation and empowerment of the individual intrapreneur. This includes, for example, sharing of accumulated managerial experience, offering strategic consulting to challenge crucial project assumptions and empower the intrapreneur in daily activities (Hornsby et al., 2002; Kuratko et al., 2014). Further, a top manager who shares the intrapreneurship project's vision and attaches explicit objectives to that vision can resolve uncertainties during project execution or compensate for imperfections in an intrapreneur's management skills. 
Top management supported projects are also likely to have more safeguarding and monitoring. Hence, project participants are likely to be more diligent, goal-oriented and less hesitant to conserve budget required to constitute project success. Based on the unique nature of intrapreneurship projects and the beneficial ramifications that top management support can lend to these types of projects as supported by insights from the case studies, I hypothesize the following relationship:

H1: Top management support is positively associated with intrapreneurship project success.

In general, organizations are configured in a way to efficiently support the core business (Rosemann \& vom Brocke, 2015). Although this configuration is usually optimized to deliver the current product portfolio, it is detrimental to creating space for innovation or intrapreneurial opportunity. As part of this organizational setup, top managers have also institutionalized this approach and tend to reinforce the status quo. A behavior that has been observed to be even more pronounced among top managers with significant tenure with the firm $(\mathrm{Wu}$, Levitas \& Priem, 2005; Srivastava \& Lee, 2005).

For large organizations, in particular, short-term incentives of top management lay the focus on near-term successes that are primarily related to the management's department or business unit objectives, in other words, their range of influence. This environment is toxic for new venture creation and intrapreneurship, which are inherently innovative undertakings that come to full fruition only over an extended period of time. It is for that reason, that top managers tend to favorize projects that bear a clear near-term benefit to personal incentives, whereas risky longterm innovation projects with highly uncertain outcomes may not find support.

Top managers' strategic foresight may grow into an adverse influence for intrapreneurship projects. For instance, a lack of technological understanding on the top management level may make it difficult to convince the hierarchy to promote intrapreneurial undertakings. This effect is reinforced by the still widely accepted practice to view unsuccessful projects as failures rather 
than opportunities for the organization to learn. Inherently, innovative undertakings such as intrapreneurship projects bear a higher risk of failure than less innovative activities closely linked to the well-understood core business. This culture surrounding top managers and intrapreneurs alike poses a threat to personal careers. It discourages intrapreneurs to initiate riskier projects and inhibits top managers from supporting those initiatives.

H2: Top management support is negatively associated with intrapreneurship project innovativeness.

For most mature organizations, innovative undertakings outside the core activities are difficult to come by, particularly so, when these undertakings are bottom-up driven like intrapreneurship projects. To yet allow these activities to flourish, adequate preconditions have to be established for intrapreneurs to pursue their initiatives. Top management plays a crucial role in creating an intrapreneurial environment in large organizations that can facilitate intrapreneurship. Unlike conventional company projects, intrapreneurship projects require a surrounding that deviates in a lot of aspects from typical organizational structures, which is why top management support is required to form an entrepreneurially friendly environment.

While traditional projects tend to use up a lot of time and resources for decision-making processes that run up and down corporate hierarchy, an intrapreneurial environment warrants intrapreneurs to assume decision responsibility within their intrapreneurship project (Sykes, 1986; Kuratko, Montagno \& Hornsby, 1990). Top managers have the ability to grant and promote deviations from typical conduct if this spurs the chances of successful intrapreneurship. In the case of equipping intrapreneurs with decision autonomy, managerial decision-making is left with the best informed in the project and avoids miscommunication across different management levels. As a result, this reduces project delays and scope adjustments, while increasing the sense of ownership for the responsible intrapreneurs. 
Besides decision autonomy, an adequate intrapreneurial environment provides sufficient time and resources to intrapreneurs. Prior research shows that a lack of time and budgetary resources limits, if not stops, intrapreneurial activity from hitting important project milestones (Kuratko, Montagno \& Hornsby, 1990). Antoncic \& Hisrich (2001) argue that limited time availability substantially impairs intrapreneurs' ability to drive their projects towards success. This is not only because relevant purchases or project contributions cannot be acquired, but it also fosters short-sightedness of the intrapreneur, which especially for an innovative undertaking can result in long-term failure. Bamber et al. (2002) find empirical evidence that constraints on financial resource intrapreneurship reduce the likelihood of high intrapreneurial performance. From traditional organizational standpoint, the chances of these detrimental conditions to happen to intrapreneurship projects are high, as the projects' strategic relevance may be misunderstood (Swink, 2000; Felekoglu \& Moultrie, 2013), the bottom-up approach is not supported or the general otherness of the intrapreneurial undertaking is penalized. Top management in support of intrapreneurship has the capacity to institutionalize programs that offer an intrapreneurial environment, while at the same time providing dedicated resources for intrapreneurial projects. Just like any other innovation project, intrapreneurship projects require a unique combination of competences and experience in order to create something new (Schumpeter, 1911). Hence, inter-departmental collaboration is needed for intrapreneurship to be successful. For one, innovative ideas breed under the eyes of experts from different fields and project challenges can be tackled using a variety of expertise. Interdisciplinary teams are rarely found in mature, matrix-structured organizations, which poses a great threat to innovative undertakings of any kind. Here again, top managers are advised to break through the structural deficiencies in order to create an intrapreneurial environment that brings together people with different competencies and the ambition to pursue intrapreneurship projects. Research by Blackwell et al. (2009) 
demonstrates that also the level of innovativeness can be improved through the successful collaboration of teams with different areas of expertise.

Based on the aforementioned arguments, I formulate the following two hypotheses:

H3a: The relationship between top management support and intrapreneurship project success is mediated by the intrapreneurial environment.

H3b: The relationship between top management support and intrapreneurship project innovativeness is mediated by the intrapreneurial environment.

Figure 1 summarizes the hypothesized relationships illustratively

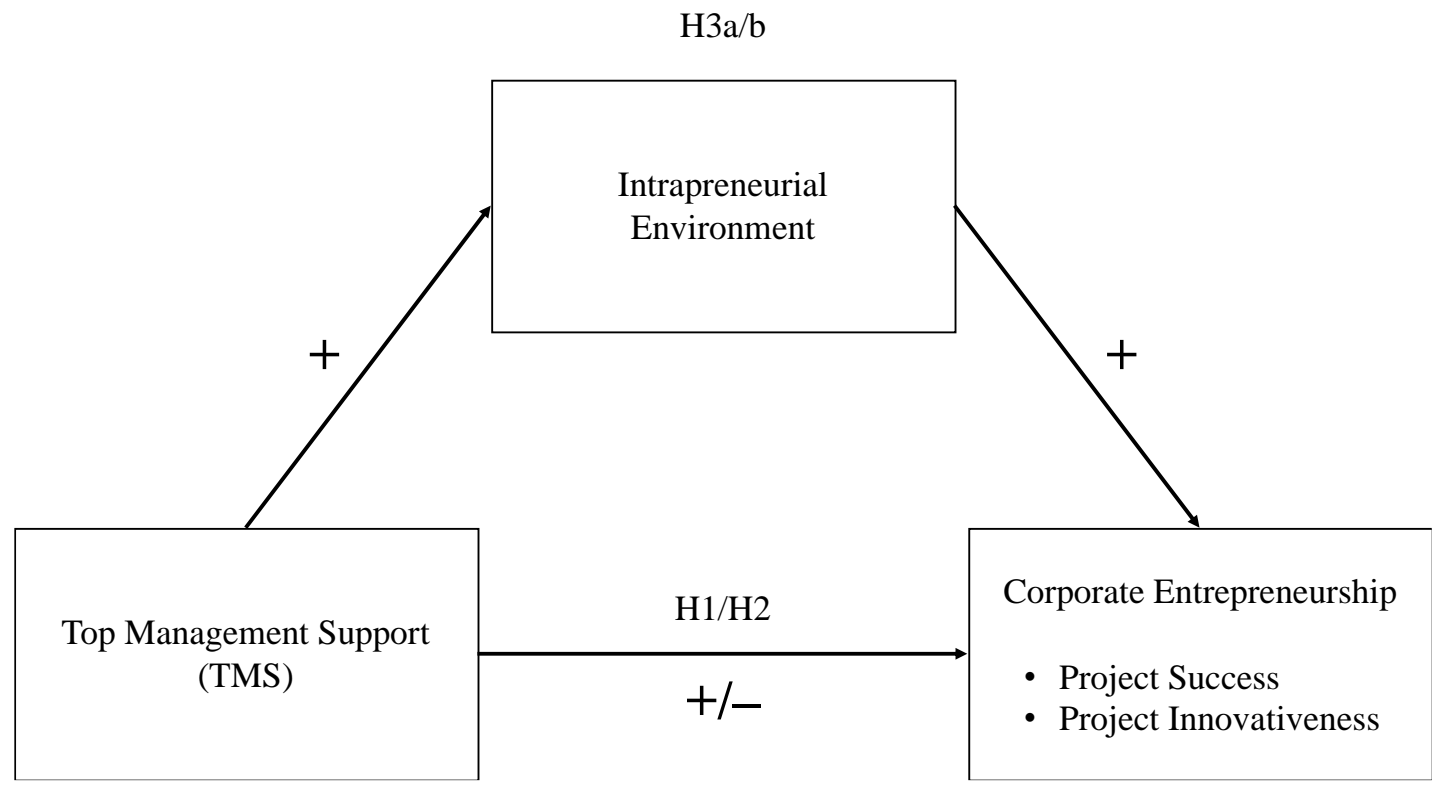

\subsection{Research and survey design}

I constructed the survey to collect primarily quantitative information in order to reduce the chances of perceptual biases. Nonetheless, ex-post rationalization may have been a cause for recall biases, which in itself could be a threat to the integrity of the data. To conduct my survey, I had to present my approach to both the company's internal data integrity board and a group of expert representatives of the workers' council. After some minor changes to a small number of questions with the sole intent to safeguard employees' personal data, the survey was approved. As a consequence, I had limited permission to collect details on participants' 
demographics as this could have enabled ourselves or researchers with access to the raw data to potentially backtrack a participant's identity.

To deliver the questionnaire to the participants, I was asked to use an internally validated software tool, again, with the intention to not be subject to any data privacy issues. The response rate was 53\% (63 out of 119 emailed surveys). This high response rate was achieved by integrating different procedures into the design of the survey (Dillman, 1983). Each survey was directly addressed to the intrapreneurs using the software issued by the company. The email included a cover letter, the survey and the affirmation that all data collected will be treated with the upmost academic standards while following the requirements delineated by the company's internal data integrity board. Completing the survey took between 20-30 minutes. Upon finalization of the data collection, a copy of aggregated results of the survey was distributed among the respondents.

\subsubsection{Dependent variables}

Interviews conducted with 10 managers responsible for intrapreneurship in their firms revealed that the evaluation of intrapreneurial projects is most frequently based on the degree of innovativeness and the project success. The outcome of intrapreneurship in this study is therefore captured by these two characteristics.

The degree of innovativeness is measured on a five-point Likert scale where respondents were asked to assess their projects' level of innovativeness from their personal viewpoint. As the degree of innovativeness is considerably determined by the prerequisites and industrial context of the company, I used that as an anchor point for the survey participants. For example, a pronounced proximity to the core business is to be associated with lower levels of innovativeness, whereas less pronounced proximity is to be related with higher degrees of innovativeness. 
Similarly, I also used a five-point Likert scale to measure intrapreneurship project success asking for the respondents' personal assessment. Due to projects' strategic heterogeneity that manifested in differing objectives, I was advised by the intrapreneurship program managers to broaden the definition of project success to capture the comprehensive benefits of intrapreneurial initiatives. For instance, while highly explorative endeavors would be considered successful if these were to yield patents to secure intellectual property in a future field, while less radical initiatives would be expected to generate topline growth or acquire market share in order to be considered a success. Hence, I also provided these criteria as reference point to the survey participants as well.

Although both variables determine the quality of an intrapreneurial project, the constructs are distinct, which is why this study treats the dependent variables as two separate outcomes in order to validate the partially opposing effects stemming from the independent variables.

\subsubsection{Independent variables}

The role of TMS has been investigated in prior studies related to job satisfaction, new product design or information systems implementation (Thong, Yap \& Raman, 1996; Viswesvaran, Deshpande \& Joseph, 1998; Swink, 2000). Based on existing literature, TMS consists of three items goal setting involvement, progress reporting and project commitment. As top managers are usually involved in the definition of corporate strategy, they are aware of strategically relevant areas and can thus facilitate a goal setting process that ensures strategic-fit of intrapreneurship projects. Based on top managers' expertise in project tracking, progress reporting is a key enabler for intrapreneurs to drive their initiatives forward, while regularly integrating feedback from experienced decision-makers (Kuratko, Montagno \& Hornsby, 1990). Moreover, top managers are able to use their influence to mitigate organizational resistance that can arise from innovation inhibiting corporate culture or general skepticism towards intrapreneurial undertakings. To measure TMS, I applied a five-point Likert scale for 
all three items. In order to safeguard inter-relatedness, I computed Cronbach's alpha for the three TMS items (Cronbach, 1951). With a value of 0.9, the internal consistency of the three items measuring the TMS construct indicates a high level of reliability.

Intrapreneurial environments in corporations, as well as its antecedents, have been explored in normative academic research almost three decades ago (Kuratko, Montagno, Hornsby, 1990), whereas the first comprehensive empirical studies emerged only a decade later (Hornsby, Kuratko \& Zahra, 2002; Kuratko et al., 2001; Hornsby, Kuratko \& Shepherd, 2009; Kuratko, Covin \& Hornsby, 2014). Until today, construct definitions vary, because, for one, different perspectives co-exist for grasping intrapreneurial environment, particularly concerning the interplay of its underlying parameters, and, two, there is continuous development in the relevant literature. Nonetheless, three components remain constant; time availability, work discretion or decision autonomy as well as interdisciplinary collaboration. Given that intrapreneurs do not receive sufficient time resources to pursue their projects, because of daily operations or limited acceptance for the project by the supervisor, the success of intrapreneurship is endangered. Similarly, a lack of decision autonomy may induce critical project delays due to slow decisionmaking by less informed supervisors or higher management. For extremely technical and innovative intrapreneurship projects, it is paramount to facilitate interdisciplinary collaboration, because a cross-functional team with different competencies is able to overcome complex project challenges effectively. To measure these variables, I used a five-point Likert scale in my survey where I asked intrapreneurs to provide an individual assessment of their work environment. Appendix B comprises the respective question.

\subsection{Results}

\subsubsection{Descriptive statistics}

Table 2 contains the descriptive statistics on variables and related questionnaire items. Project Innovativeness stands out, because the Likert scale's theoretical maximum ( 5 - strongly agree) 
for the item has not been used, resulting in the lowest mean of all variables (1.86). Responses by surveyed intrapreneurs indicate that the level of innovativeness has not been perceived particularly high. The reason for this could be attributed to the fact that intrapreneurs generally are highly innovative and forward-thinking, which is why and these respondents would assess intrapreneurship projects to have a comparably low level of innovativeness. Top Management Support and Time Availability show the highest means (2.73 and 2.79 respectively), further, these two variables are positively correlated with a correlation coefficient of 0.33 . Moreover, TMS is significantly correlated with Internal Network and Project Success (correlation coefficient of 0.27 and 0.37 respectively). The analysis also shows a positive and significant correlation for Project Success with Time Availability as well as Project Innovativeness with Internal Network (correlation coefficient of 0.27 and 0.36 respectively). From the intercorrelation matrix one can also see that none of the variables exhibit extremely high correlations, which is why the threat of multicollinearity can be ruled out for the data set at hand.

\begin{tabular}{lccccccccccc}
\hline & \multicolumn{1}{c}{ TABLE 2 } & & & & & & \\
& \multicolumn{1}{c}{$\begin{array}{c}\text { Descriptive statistics on variables and } \\
\text { related questionnaire items }\end{array}$} & & & & & \\
& Min & Max & Mean & Std. Dev. & 1 & 2 & 3 & 4 & 5 & 6 \\
\hline Top Management Support & 1 & 5 & 2.73 & 1.10 & 1 & & & & & \\
Time Availability & 1 & 5 & 2.79 & 1.19 & 0.33 & 1 & & & \\
Decision Autonomy & 1 & 5 & 2.02 & 1.02 & 0.17 & 0.19 & 1 & & \\
Internal Network & 1 & 5 & 1.97 & 1.14 & 0.27 & -0.16 & -0.07 & 1 & & \\
Project Innovativeness & 1 & 4 & 1.86 & 0.98 & -0.07 & -0.09 & -0.05 & 0.36 & 1 & \\
Project Success & 1 & 5 & 2.43 & 1.24 & 0.37 & 0.27 & 0.15 & 0.24 & 0.25 & 1 \\
\hline
\end{tabular}

\subsubsection{Hypotheses tests}

To test the proposed hypotheses, I conducted multiple OLS regressions that are comprised in Table 2 using data from 63 completed surveys. I specify the following model to test H1:

$$
\text { Project Success }=\alpha 0+\alpha 1 \text { Top Management Support }+\varepsilon 1
$$


The results show a positive and statistically significant relationship between Top Management Support and Project Success $(\alpha 1=0.240$, p-value $<0.1)$. The outcome suggests that the support of top managers is a prerequisite for the success of intrapreneurship projects in large corporations. This finding concurs with similar insights from prior research, where support of higher management has been a crucial determinant for new product development or long-term oriented strategic projects (Pinto \& Slevin, 1987; Sumner, 1999; Belout \& Gauvreau, 2004). From a perspective of intrapreneurship literature, top management is capable of positively influencing the environment for intrapreneurs on an organizational level while encouraging intrapreneurs on an individual level to take entrepreneurial risk in order to contribute to sustainable company performance (Kuratko, Montagno \& Hornsby, 1990; Swink, 2000; Hornsby et al., 2009).

To investigate H2, I construct Model 2 as follows:

$$
\text { Project Innovativeness }=\alpha 0+\alpha 1 \text { Top Management Support }+\varepsilon 2
$$

The statistical analysis reveals a non-significant relationship between Top Management Support and Project Innovativeness. Moreover, the explanatory power of the model is low with an adjusted R-squared of .01, suggesting a suboptimal model fit. Hence, I was unable to confirm H2 using model 2, although the coefficient of Top Management Support exhibits a negative $\operatorname{sign}(\alpha 1=-0.143, \mathrm{p}$-value $=0.162)$.

To shed light on how the relationship between Top Management Support and Project Success is mediated by factors of intrapreneurial environment, I first formulate Model 3:

$$
\begin{gathered}
\text { Project Success }=\alpha 0+\alpha 1 \text { Top Management Support }+\alpha 2 \text { Time Availability } \\
+\alpha 3 \text { Decision Autonomy }+\alpha 4 \text { Internal Network }+\varepsilon 3
\end{gathered}
$$

The analysis shows that Top Management Support remains to be positive, yet not statistically significant related to Project Success $(\alpha 1=0.123)$. Introducing Time Availability, Decision Autonomy and Internal Network as control variables, the outcome reveals that all 
intrapreneurial environment variables exhibit positive coefficients, but none are statistically significant. Further, Appendix C comprises mediation tests for the respective intrapreneurial environment factors using the Sobel test (Preacher \& Hayes, 2004; Preacher \& Hayes, 2008). Although my preliminary results suggest confirmation that TMS is a key antecedent for an intrapreneurial environment, a mediation is not supported. The p-values of the Sobel statistics for the variables Time Availability, Decision Autonomy and Internal Network are 0.238, 0.529 and 0.286 respectively.

To test $\mathrm{H} 3 \mathrm{~b}$, whether intrapreneurial environment factors mediate the relationship between Top Management Support and Project Innovativeness, I defined model 4 as follows:

$$
\begin{gathered}
\text { Project Innovativeness }=\alpha 0+\alpha 1 \text { Top Management Support }+\alpha 2 \text { Time Availability } \\
+\alpha 3 \text { Decision Autonomy }+\alpha 4 \text { Internal Network }+\varepsilon 4
\end{gathered}
$$

The analysis shows that Top Management Support remains to be negative and becomes statistically significant related to Project Success $(\alpha 1=-0.202$, p-value $<0.1)$. The results indicate that Time Availability and Decision Autonomy do not have a statistically significant impact on Project Innovativeness, whereas the Internal Network is significantly and positively related to Project Innovativeness $(\alpha 4=0.343, \mathrm{p}$-value $<0.01)$. Based on the outcome, I can infer that the provision of a cross-departmental collaboration through an internal company network increases the level of innovativeness of intrapreneurial projects. Prior research by Blackwell et al. (2009) and Alves et al. (2007) has found evidence on a similar effect in innovation management and NPD, it shows that multidisciplinary collaboration fuels creativity and supports innovation processes. Analogous to $\mathrm{H} 3 \mathrm{a}$, Appendix $\mathrm{C}$ comprises mediation tests for the respective intrapreneurial environment factors, again, using the Sobel test. Based on the respective models, the p-values of the Sobel test statistics for the variables Time Availability, Decision Autonomy and Internal Network are $0.564,0.793$ and 0.069 respectively. The results reveal that Internal Network has a significantly positive mediation effect on the relationship 
between Top Management Support and Project Innovativeness $(\alpha 4=1.813$, p-value $<0.1)$. That implies that the marginal significant negative relationship between TMS and Project Innovativeness delineated prior is augmented by facilitating intrapreneurial projects with access to a cross-departmental network within the organization. With this end in mind, the provision of an intrapreneurial environment that supports internal collaboration is a central duty of top managers to ensure high levels of project innovativeness, while reconfirming that their general project support does not deter an intrapreneur's initiative.

Revisiting the test results for $\mathrm{H} 2$, using Model 4 to control for the intrapreneurial environment factors, Top Management Support becomes statistically significant for a two-tailed distribution $(\alpha 1=-0.202, p$-value $<0.01)$. Hence, the impact of supportive top management, also within an intrapreneurial environment, still cannot be conclusively delineated. Yet, the statistical results align with arguments made prior by Swink (2000), who suggests that top management support, and thereby their involvement, can deter a project's innovativeness due to top managers' potentially low technical understanding required for the project as well as involvement turning into continuous tracking that interferes with independent intrapreneurial principle to empower intrapreneurs.

\begin{tabular}{|c|c|c|c|c|}
\hline \multicolumn{5}{|c|}{$\begin{array}{c}\text { TABLE } 3 \\
\text { OLS Regression Models }\end{array}$} \\
\hline & $\begin{array}{c}\text { Dependent } \\
\text { Variable: } \\
\text { Project Success }\end{array}$ & $\begin{array}{l}\text { Dependent } \\
\text { Variable: } \\
\text { Project } \\
\text { Innovativeness }\end{array}$ & $\begin{array}{c}\text { Dependent } \\
\text { Variable: } \\
\text { Project Success }\end{array}$ & $\begin{array}{c}\text { Dependent } \\
\text { Variable: } \\
\text { Project } \\
\text { Innovativeness }\end{array}$ \\
\hline Explanatory Variables & Model 1 & Model 2 & Model 3 & Model 4 \\
\hline $\begin{array}{l}\text { Top Management Support } \\
\text { Time Availability } \\
\text { Decision Autonomy } \\
\text { Internal Network } \\
\text { Constant } \\
\end{array}$ & $1.643 * * *$ & $2.223 * * *$ & $\begin{array}{l}0.123 \\
0.208 \\
0.144 \\
0.111 \\
0.850 \\
\end{array}$ & $\begin{array}{l}-0.202 * \\
0.052 \\
0.021 \\
0.343 * * * \\
1.510 * * * \\
\end{array}$ \\
\hline $\begin{array}{l}\text { Number of Observations (N) } \\
\text { Adjusted R-squared }\end{array}$ & $\begin{array}{c}63 \\
0.032 \\
\end{array}$ & $\begin{array}{c}63 \\
0.016 \\
\end{array}$ & $\begin{array}{c}63 \\
0.031 \\
\end{array}$ & $\begin{array}{c}63 \\
0.123 \\
\end{array}$ \\
\hline
\end{tabular}




\subsection{Discussion and conclusion}

This study investigates the role of TMS in intrapreneurship and sheds light on the effects an intrapreneurial environment has on this relationship. Based on existing literature as well as a comprehensive case study, I dissect the constituents of TMS and devise the elements of intrapreneurial environment. From the analysis, I develop a comprehensive questionnaire for intrapreneurs to examine underlying mechanisms that drive success and innovativeness in intrapreneurship projects. I find that TMS has a positive impact on intrapreneurship project success, while its effect on intrapreneurship project innovativeness is marginally negative. As I hypothesized, characteristics of intrapreneurial environment, like time availability and internal network, can also be beneficial for project innovativeness. My results also confirm that an intrapreneur's internal company network positively mediates the relationship between TMS and project innovativeness.

From the results, I find that the role of top managers is ambidextrous. For one, top management is responsible for (re-)shaping organizational structures by overcoming innovation adverse processes or proactively address middle management concerns. On the other hand, top managers need to make way for intrapreneurs themselves, to avoid undermining competent and ambitious intrapreneurs in their pursuit of creating a new business venture to contribute to overall company performance. Conversely, intrapreneurs expect top managers to assume an empowering function that consists of sparring, experience and the provision of their personal network. The latter is to be achieved through the creation of an intrapreneurial environment by top managers to facilitate intrapreneurs' pursuit of a venture building. Although some interviewees in the case studies have indicated that an artificial time shortage may reveal intrapreneurs' commitment to their projects as selection criteria for intrapreneurs, this study, however, suggests that for running intrapreneurship projects time availability can be a contributor of success. Consistent with the case studies, the empirical analysis confirms that 
particularly for bottom-up initiatives like intrapreneurship, an internal network is critical for the success, but also for the innovativeness of intrapreneurship. On the one hand, an internal network supports in accelerating processes to overcome organizational inertia, while on the other hand, collaboration with colleagues from other disciplines fuels creativity and extends an intrapreneur's problem-solving competence (Dess \& Lumpkin, 1999; Kelley et al., 2009).

This research contributes to the existing body of literature on intrapreneurship. I contribute to a growing demand to reevaluate current understanding of intrapreneurship from a practitioner's point of view, as most large corporations still struggle to leverage intrapreneurship to its fullest potential $^{4}$ (Gundogdu, 2012). Further, a reassessment of the top management's facilitation role paired with the insights on intrapreneurial environment as antecedent of successful intrapreneurship projects combines latest theoretical fundament with today's intrapreneurship practice in some of Europe's largest corporations. To the best of my knowledge, the qualitative case study data on intrapreneurship program managers is unique and provides unprecedented insights how large corporations have institutionalized intrapreneurship. I find that generally applicable antecedents of intrapreneurship may not have a significant impact on success and innovativeness of intrapreneurship projects. Fundamental research by Antoncic \& Hisrich (2001) and Hornsby et al. (1990) claims that both environment, as well as organizational prerequisites, determine the outcome of intrapreneurial undertakings. My case study insights suggest that the primary determinant of intrapreneurship success stems from internal circumstances, such as top management support and intrapreneurial environment, only when that is given the external perspective comes into play. Compared to prior literature, this study delivers new insights from intrapreneurs in a large corporation, because instead of assuming a strategic bird's eye view on the topic at hand, I scrutinize the phenomenon on the level of the

\footnotetext{
${ }^{4}$ Case study participants have signaled that many are still struggling in reaping the full benefits of corporate entrepreneurship in their respective firms
} 
intrapreneur. Understanding the organizational requirements from the intrapreneur's perspective is equally important to comprehend intrapreneurship success, particularly because intrapreneurship is a bottom-up initiative.

The role of top managers in intrapreneurship is newly established in my research. In the past, researchers have either focused on TMS as component of organizational support in the context of intrapreneurship, while others have merely linked TMS with innovation projects or new product development (Swink, 2000; Gomes et al., 2001; Islam et al., 2009). My study develops creates a new understanding of the responsibilities of top managers in large organizations to ensure intrapreneurship success. My empirical results show that top managers' duties are not limited to supporting intrapreneurs on an organizational or individual level, but also facilitating intrapreneurial environment to ensures project innovativeness and overall intrapreneurship success.

Like any other scholarly endeavor, this study is subject to some limitations. First, I selected case study participants based on web research results of large corporations in Europe that publicly communicated their intrapreneurship activities with a dedicated intrapreneurship program and accepted to be interviewed when inquired via email through my university. Hence, my study may not have inquired corporations active in intrapreneurship, which have not publicly announced this or did not respond to my inquiry. Second, the limited sample size of 119 intrapreneurs as survey participants could be alleviated, however, due to the rather short lifespan of institutionalized intrapreneurship the number of intrapreneurs is constraint even within large organizations. Third, survey research is commonly subject to perception biases. As I questioned intrapreneurs to answer the survey items based on their personal experience, perception bias cannot be ruled out in my study either. Fourth, as requirement to conduct survey research, it was merely permitted to collect demographics on survey participants. Although this request is comprehensible from a data privacy standpoint, I may have missed some important 
personal characteristics of intrapreneurs as suggested by prior research on intrapreneurs' personalities (Sayeed \& Gazdar, 2003; Camelo-Ordaz et al., 2012; Hydle et al., 2014; Mohedano-Suanes \& Benitez, 2018). Fifth, although my case studies support the idea that TMS is in fact an antecedent of intrapreneurship, it could be argued that this relationship is subject to reverse causality because the interviewees in the case study are not the same as the survey participants. Nonetheless, the case studies lend support to the described relationship in my study, even though in practice one can observe that success has many parents which could allude a reverse relationship. Lastly, my entire research has been conducted in Europe, hence my findings may not be generally applicable in the US, Asia or other areas of the world as cultural differences may require distinct antecedents to induce successful intrapreneurship, which may not have been revealed in my study.

This scholarly work can be extended in several directions. While the role of top managers in intrapreneurship is delineated in detail in this paper, the effect of top management incentives on the relationship between TMS and intrapreneurship represents a promising area of future research. Similarly, the literature lacks an in-depth understanding of intrapreneurs' incentives and their influence on intrapreneurship success. Furthermore, limited empirical work is found on the relationship of top managers and intrapreneurs. Trust and confidence in this relationship could significantly drive the probability of intrapreneurship success under consideration of the bottom-up nature of intrapreneurship. Anecdotal evidence provides accounts that intrapreneurship happens in American, European and Asian firms, which raises the question of cultural distinctions in intrapreneurship. Lastly, only very few studies have been able dissect the economic impact on intrapreneurship at the firm level, because primarily proxies such as patents or new ventures have been utilized to date. To advance the knowledge about intrapreneurship, the exploration of firm performance implications of intrapreneurship is yet another intriguing area for future research. 


\section{Conclusion}

In this dissertation, I examine two phenomena related to corporates' inertia to innovate. First, I investigate effects of providing non-diagnostic information in risky capital budgeting decisions and how there are limits of providing information to decision-makers to facilitate capital budgeting tasks for risky projects. Although decision-makers tend to receive more and more information in practice, which is primarily due to decreasing costs to acquire information, my research shows that this can trigger suboptimal decision-making due to the integration of irrelevant information in the decision process. Whereas a suboptimal resource allocation to innovation projects is a main reason for failed corporate innovation (Bladwin, 1991). Second, I scrutinize the role of top managers in innovative intrapreneurship projects and how leading decision-makers in organizations can facilitate the success of intrapreneurial undertakings. While traditional corporate virtues like short-sighted management incentives, limited technological expertise and thorough project controlling tend to hinder an innovation-driven surrounding, I analyze top management behaviors that induce success and innovativeness of intrapreneurship projects.

\subsection{Summary}

In chapter 2, my research shows that nondiagnostic information creates a dilution effect in capital budgeting decisions thereby reducing investments. I find this effect to be more pronounced as more nondiagnostic information is provided. My results demonstrate that decision makers exposed to high risk, invest significantly less as compared to their peers in a low-risk setting. I find decision makers to utilize more nonfinancial information for their decision-making processes in the absence of risk and cognitive load. This is in line with general advocacy in accounting literature, to compliment capital budgeting tasks with nonfinancial information to generate a more comprehensive decision fundament. However, decision makers' behavior changes when exposed to high cognitive load, which leads to a reduction of 
nonfinancial information, such that more familiar financial information is preferred and used. In the light of high risk, decision makers show indifferent behavior towards financial and nonfinancial information. My findings underline that there are beneficial limits to providing more information to decision makers, particularly when these are of nondiagnostic nature. The use of nonfinancial information, although deemed recommended by former research, can be deteriorated by cognitive load, bringing decision makers to favor familiar, financial information.

In chapter 3, I show that TMS has a positive impact on intrapreneurship project success, while its effect on intrapreneurship project innovativeness is arguably negative. My results also confirm that an intrapreneur's internal company network positively mediates the relationship between TMS and project innovativeness. From the results, I find that the role of top managers is ambidextrous. Top managers are responsible for (re-)shaping organizational structures by overcoming innovation adverse processes, while proactively addressing other managers' concerns. Further, top management needs to make way for intrapreneurs themselves, to avoid undermining competent and ambitious intrapreneurs in their pursuit of novel business ventures to contribute to overall firm performance. Conversely, intrapreneurs expect top managers to assume an empowering function that consists of sparring, experience and the provision of their personal network. The latter is to be achieved through the creation of an intrapreneurial environment by top managers to facilitate intrapreneurs' pursuit of a venture building. Consistent with the case studies, the empirical analysis confirms that particularly for bottomup initiatives like intrapreneurship, an internal network is critical for the success, but also for the innovativeness of intrapreneurship.

\subsection{Contributions and implications}

Chapter 2 adds manifold to the scarcity of research in the domain of capital budgeting behavior.

First, the study contributes to a growing stream of literature on the use of information in 
decision processes and provides empirical evidence that more information is not necessarily better. Particularly more nondiagnostic information induces suboptimal capital budgeting decisions. Second, I show the existence of the dilution effect to occur also in capital budgeting decisions, meaning that the provision of information must also consider whether data is diagnostic or nondiagnostic to decision makers, because nondiagnostic information can cause a deviation from optimal decision behavior. Third, my study observed that decision makers exhibit varying preferences towards different types of information depending on the decision context. I show that more nonfinancial information is only used in the absence of cognitive load and risk. This indicates that a behavior advocated by leading researchers to integrate nonfinancial information into an investment decision is only upheld when decision makers do not face challenging circumstances in the decision process. These findings have significant managerial implications for example for the design of management information systems in capital budgeting. It is not only the amount of information that is relevant but also the type of information depending on the level of risk and cognitive load. As such, my research can provide guidance on how to structure and improve the process of capital budgeting.

Chapter 3 contributes to the growing body of literature on intrapreneurship, particularly so from a practitioner's point of view, because most large corporations still struggle to leverage intrapreneurship fully, which is why I set out to reevaluate the current understanding in the field. Further, a reassessment of the top management's facilitation role paired with the insights on intrapreneurial environment as antecedent of successful intrapreneurship projects combines latest theoretical fundament with today's intrapreneurship practice in some of Europe's largest corporations. My unique case studies provide invaluable insights into the proceedings of large corporations in the context of intrapreneurship. My study shows that generally applicable antecedents of intrapreneurship may not have a significant impact on success and innovativeness of intrapreneurship projects. Fundamental research by Antoncic \& Hisrich 
(2001) and Hornsby et al. (1990) claims that both environment, as well as organizational prerequisites, determine the outcome of intrapreneurial undertakings. My case studies suggest that the primary determinant of intrapreneurship success stems from internal circumstances, only when that is given the external environment becomes relevant. My study also contributes to the existing body of literature by scrutinizing the intrapreneurship phenomenon on the level of the intrapreneur, rather than assuming a bird's eye view on the topic to establish topographical understanding. This is particularly valuable because intrapreneurship in its essence is a bottom-up initiative.

In my research, I reestablish the role of top managers in intrapreneurship. While in the past, scholars have either concentrated on TMS as a part of organization support in the domain of intrapreneurship or focused on TMS in relation to new product development, my study develops a new understanding of the responsibilities of top managers in large organizations to enable successful intrapreneurial activities. My research shows that top managers' duties are not limited to supporting intrapreneurs on an organizational or individual level, but much more facilitating an entrepreneurial environment that allows intrapreneurs to excel with their projects from an innovativeness standpoint but also to secure successful outcomes.

\subsection{Limitations and future research}

Like any other scholarly work, my study in chapter 2 is subject to some limitations that could stimulate future research. First, my research has been conducted in a laboratory setting, which makes it by definition a simplification of a real-world environment. Hence, there is great opportunity to run field research with corporate managers to gather more evidence to contribute this stream of research. Second, in my experiment, I issued nondiagnostic information in an unstructured fashion to preclude perception bias. Prior research has shown that the structure how information is presented can affect decision outcomes, which is why future research could investigate the impact stemming from the way nondiagnostic information is provided to 
decision makers. Third, I observed information preferences only for nondiagnostic information, which is why research concerning preferences with diagnostic information could confirm the idea that information preferences change depending on the decision environment. Lastly, my study has merely scrutinized two aspects that can influence managers' capital budgeting behavior. It would therefore be desirable for future research to investigate concrete strategies that can alleviate the dilution effect in capital budgeting decisions.

Chapter 3 also contains some limitations that can be explored by future research. First, I only selected case study participants based on a web analysis of large corporations in Europe that have publicly announced their intrapreneurship activities with a dedicated intrapreneurship program. Hence, my study can be complemented with insights from any corporation whose employees are engaging in intrapreneurial activity. Second, the case studies provided support for the causal relationship between TMS and intrapreneurship, nonetheless, there is evidence that could suggest a reverse-causality, given that many top managers support successful intrapreneurial initiatives ex-post. In other words, success has many parents, but failure is always an orphan. Third, the limited sample size of 119 intrapreneurs as survey participants could be extended and further validated by integrating intrapreneurs from multiple organizations with awareness to the increasing complexity of the statistical models. Fourth, my survey research can be subject to perception bias, which is why more scholarly work in this context to triangulate findings can reduce the risk of perception bias in my study. Fifth, as requirement to conduct my survey research, I was not permitted to collect all relevant demographic data of the participants, which would have been insightful to understand more about the personality and origin of the intrapreneurs, these differences could surely be explored in future research. Similarly, my study has taken a purely European perspective on intrapreneurship, which is why it would certainly be interesting to compare my findings with 
insights from other regions of the world, for example China, Japan or the US, to reveal cultural discrepancies in how to make intrapreneurship a success. 


\section{References}

Ackoff, R. L. 1967. Management misinformation systems. Management Science 14 (4): B-147-B-156.

Adler, P. S., \& Chen, C. X. (2011). Combining creativity and control: Understanding individual motivation in large-scale collaborative creativity. Accounting, organizations and society, 36(2), 63-85.

Agnew, J. R., \& Szykman, L. R. (2005). Asset allocation and information overload: The influence of information display, asset choice, and investor experience. The Journal of Behavioral Finance, 6(2), 57-70.

Ahmed, A. S., \& Duellman, S. (2013). Managerial overconfidence and accounting conservatism. Journal of Accounting Research, 51(1), 1-30.

Alpkan, L., Bulut, C., Gunday, G., Ulusoy, G., \& Kilic, K. (2010). Organizational support for intrapreneurship and its interaction with human capital to enhance innovative performance. Management decision, 48(5), 732-755.

Alves, J., Marques, M. J., Saur, I., \& Marques, P. (2007). Creativity and innovation through multidisciplinary and multisectoral cooperation. Creativity and innovation management, 16(1), 27-34.

Anderson, N. H. 1971. Integration theory and attitude change. Psychological Review 78(3): 171-206.

Antoncic, B. (2001). Organizational processes in intrapreneurship: a conceptual integration. Journal of Enterprising Culture, 9(02), 221-235.

Antoncic, B., \& Hisrich, R. D. (2001). Intrapreneurship: Construct refinement and cross-cultural validation. Journal of business venturing, 16(5), 495-527.

Antoncic, B., \& Zorn, O. (2004). The mediating role of corporate entrepreneurship in the organizational support-performance relationship: An empirical examination. Managing global transitions, 2(1), 5.

Antoncic, B. (2007). Intrapreneurship: a comparative structural equation modeling study. Industrial Management \& Data Systems, 107(3), 309-325.

Baldwin, C. Y. (1991). How capital budgeting deters innovation-and what to do about it. Research-Technology Management, 34(6), 39-45. 
Bamber, D., Owens, J., Davies, J., \& Suleman, A. (2002). Enabling the emergent entrepreneurial organisation to develop new products. International Journal of Entrepreneurial Behavior \& Research, 8(4), 203-221.

Banker, R. D., G. Potter, and D. Srinivasan. 2000. An empirical investigation of an incentive plan that includes nonfinancial performance measures. The Accounting Review 75 (1): 65-92.

Banker, R. D., Chang, H., \& Pizzini, M. J. (2004). The balanced scorecard: Judgmental effects of performance measures linked to strategy. The Accounting Review, 79(1), 1-23.

Bantel, K. A., \& Jackson, S. E. (1989). Top management and innovations in banking: does the composition of the top team make a difference?. Strategic management journal, 10(S1), 107-124.

Barringer, B. R., \& Bluedorn, A. C. (1999). The relationship between corporate entrepreneurship and strategic management. Strategic management journal, 20(5), 421-444.

Bedford, D. S. (2015). Management control systems across different modes of innovation: Implications for firm performance. Management Accounting Research, 28, 12-30.

Belout, A., \& Gauvreau, C. (2004). Factors influencing project success: the impact of human resource management. International journal of project management, 22(1), 1-11.

Benjamin, D. J., Brown, S. A., \& Shapiro, J. M. (2013). Who is 'behavioral'? Cognitive ability and anomalous preferences. Journal of the European Economic Association, 11(6), 1231-1255.

Berk, J. B., and P. M. DeMarzo. 2007. Corporate finance. Pearson Education.

Bhimani, A., \& Langfield-Smith, K. (2007). Structure, formality and the importance of financial and non-financial information in strategy development and implementation. Management accounting research, 18(1), 3-31.

Birkinshaw, J., \& Ridderstråle, J. (1999). Fighting the corporate immune system: a process study of subsidiary initiatives in multinational corporations. International Business Review, 8(2), 149-180.

Bisbe, J., \& Otley, D. (2004). The effects of the interactive use of management control systems on product innovation. Accounting, organizations and society, 29(8), 709-737. 
Blackwell, A. F., Wilson, L., Boulton, C., \& Knell, J. (2009). Radical innovation: crossing knowledge boundaries with interdisciplinary teams (No. UCAM-CL-TR-760). University of Cambridge, Computer Laboratory.

Brazeal, D. V. (1993). Organizing for internally developed corporate ventures. Journal of Business venturing, 8(1), 75-90.

Brown-Liburd, H., H. Issa, and D. Lombardi. 2015. Behavioral implications of Big Data's impact on audit judgment and decision making and future research directions. Accounting Horizons 29 (2): 451-68.

Brüggen, A., Feichter, C., \& Williamson, M. G. (2017). The effect of input and output targets for routine tasks on creative task performance. The Accounting Review, 93(1), 29-43.

Burgelman, R. A. (1983). A process model of internal corporate venturing in the diversified major firm. Administrative science quarterly, 223-244.

Burgelman, R. A. (1984). Designs for corporate entrepreneurship in established firms. California management review, 26(3), 154-166.

Burns, R. M., and J. Walker. 1997. Capital budgeting techniques among the Fortune 500: A rationale approach. Managerial Finance 23 (9): 3-15.

Camelo-Ordaz, C., Fernández-Alles, M., Ruiz-Navarro, J., \& Sousa-Ginel, E. (2012). The intrapreneur and innovation in creative firms. International Small Business Journal, 30(5), 513-535.

Cardinaels, E., and P. M. van Veen-Dirks. 2010. Financial versus non-financial information: The impact of information organization and presentation in a Balanced Scorecard. Accounting, Organizations and Society 35 (6): 565-78.

Carrier, C. (1994). Intrapreneurship in large firms and SMEs: a comparative study. International Small Business Journal, 12(3), 54-61.

Chen, S. 2008. DCF techniques and nonfinancial measures in capital budgeting: A contingency approach analysis. Behavioral Research in Accounting 20 (1): 13-29.

Chewning, E. G., Jr., and A. M. Harrell. 1990. The effect of information load on decision makers' cue utilization levels and decision quality in a financial distress decision task. Accounting, Organizations and Society 15 (6): 527-42.

Chittenden, F., and M. Derregia. 2015. Uncertainty, irreversibility and the use of 'rules of thumb' in capital budgeting. The British Accounting Review 47 (3): 225-36. 
Chow, C. W., and W. A. Van der Stede. 2006. The use and usefulness of nonfinancial performance measures. Management Accounting Quarterly 7 (3): 1-8.

Cooper, R. B. (1988). Review of management information systems research: A management support emphasis. Information Processing \& Management, 24(1), 73-102.

Cooper, J. R. (1998). A multidimensional approach to the adoption of innovation. Management decision, 36(8), 493-502.

Covin, J. G., \& Slevin, D. P. (1989). Empirical relationship among strategic posture environmental context variables, and new venture performance. Frontiers Entrepreneurship Research, 16(5), 124-133.

Cronbach, L. J. (1951). Coefficient alpha and the internal structure of tests. psychometrika, 16(3), 297-334.

Davila, T. (2000). An empirical study on the drivers of management control systems' design in new product development. Accounting, organizations and society, 25(4-5), 383-409.

Davila, A., Foster, G., \& Li, M. (2009). Reasons for management control systems adoption: Insights from product development systems choice by early-stage entrepreneurial companies. Accounting, Organizations and Society, 34(3-4), 322-347.

Dean Jr, J. W., \& Sharfman, M. P. (1996). Does decision process matter? A study of strategic decision-making effectiveness. Academy of management journal, 39(2), 368-392.

Deloitte (2015). Five Insights into Intrapreneurship. Web: https://www2.deloitte.com/content/dam/Deloitte/de/Documents/technology/Intrapreneurship Whitepaper_English.pdf

Denscombe, M. (2008). Communities of practice: A research paradigm for the mixed methods approach. Journal of mixed methods research, 2(3), 270-283.

Dess, G. G., Lumpkin, G. T., \& McGee, J. E. (1999). Linking corporate entrepreneurship to strategy, structure, and process: Suggested research directions. Entrepreneurship theory and practice, 23(3), 85-102.

Dess, G. G., Ireland, R. D., Zahra, S. A., Floyd, S. W., Janney, J. J., \& Lane, P. J. (2003). Emerging issues in corporate entrepreneurship. Journal of management, 29(3), 351-378. 
Dess, G. G., \& Lumpkin, G. T. (2005). The role of entrepreneurial orientation in stimulating effective corporate entrepreneurship. Academy of Management Perspectives, 19(1), 147-156.

Dillman, D. A. (1983). Mail and other self-administered questionnaires. Handbook for survey research, 359-377.

Doherty, M. E., C. R. Mynatt, R. D. Tweney, and M. D. Schiavo. 1979. Pseudodiagnosticity. Acta Psychologica 43 (2): 111-21.

Doherty, M. E., M. B. Schiavo, R. D. Tweney, and C. R. Mynatt. 1981. The influence of feedback and diagnostic data on pseudodiagnosticity. Bulletin of the Psychonomic Society 18 (4): 191-94.

Lovallo, D., Koller, T., Uhlaner, R., \& Kahneman, D. (2020). Your Company Is Too Risk-Averse. Harvard Business Review, 98(2), 104-111.

Eppler, M. J., and J. Mengis. 2004. The concept of information overload: A review of literature from organization science, accounting, marketing, MIS, and related disciplines. The Information Society 20 (5): 325-44.

Ettlie, J. E., Bridges, W. P., \& O'keefe, R. D. (1984). Organization strategy and structural differences for radical versus incremental innovation. Management science, 30(6), 682-695.

Fein, S., and J. L. Hilton. 1992. Attitudes toward groups and behavioral intentions toward individual group members: The impact of nondiagnostic information. Journal of Experimental Social Psychology 28 (2): 101-24.

Felekoglu, B., \& Moultrie, J. (2014). Top management involvement in new product development: A review and synthesis. Journal of Product Innovation Management, 31(1), 159175.

Fischbacher, U. 2007. z-Tree: Zurich toolbox for ready-made economic experiments. Experimental Economics 10 (2): 171-78.

Fry, A. (1987). The post-it note: An intrapreneurial success. SAM Advanced Management Journal, 52(3), 4.

Gaeth, G. J., and J. Shanteau. 1984. Reducing the influence of irrelevant information on experienced decision makers. Organizational Behavior and Human Performance 33 (2): 26382. 
Gapp, R., \& Fisher, R. (2007). Developing an intrapreneur-led three-phase model of innovation. International Journal of Entrepreneurial Behavior \& Research, 13(6), 330-348.

Gerhardt, H. (2013). Essays in experimental and neuroeconomics.

Gersick, C. J., \& Hackman, J. R. (1990). Habitual routines in task-performing groups. Organizational behavior and human decision processes, 47(1), 65-97.

Gigerenzer, G., and W. Gaissmaier. 2011. Heuristic decision making. Annual Review of Psychology 62: 451-82.

Gilbert, C., \& Bower, J. L. (2002). Disruptive change. When trying harder is part of the problem. Harvard business review, 80(5), 94-101.

Glover, S. M. 1997. The influence of time pressure and accountability on auditors' processing of nondiagnostic information. Journal of Accounting Research 35 (2): 213-26.

Gomes, J., De Weerd-Nederhof, P. C., Pearson, A., \& Fisscher, O. A. (2001). Senior management support in the new product development process. Creativity and Innovation Management, 10(4), 234-242.

Gorla, N., T. M. Somers, and B. Wong. 2010. Organizational impact of system quality, information quality, and service quality. The Journal of Strategic Information Systems 19 (3): 207-28.

Gorry, G. A., and M. S. Morton. 1989. A framework for management information systems. Sloan Management Review 30 (3): 49-61.

Gündoğdu, M. Ç. (2012). Re-thinking entrepreneurship, intrapreneurship, and innovation: A multi-concept perspective. Procedia-Social and Behavioral Sciences, 41, 296303.

Grabner, I. (2007). Managing Organizational Creativity Motivational aspects of management control systems for creative employees. Wirtschaftsuniversität Wien, Nordbergstrasse, 15.

Hackenbrack, K. 1992. Implications of seemingly irrelevant evidence in audit judgment. Journal of Accounting Research 30 (1): 126-136.

Hayton, J. C. (2005). Promoting corporate entrepreneurship through human resource management practices: A review of empirical research. Human resource management review, $15(1), 21-41$. 
Hoff, B., and D. Wood. 2008. The use of non-financial information: what do investors want? White paper, Institute for Responsible Investment, Boston.

Hoffmann, J. A., von Helversen, B., \& Rieskamp, J. (2013). Deliberation's blindsight: How cognitive load can improve judgments. Psychological science, 24(6), 869-879.

Hoffman, V. B., and J. M. Patton. 1997. Accountability, the dilution effect, and conservatism in auditors' fraud judgments. Journal of Accounting Research 35 (2): 227-37.

Holt, D. T., Rutherford, M. W., \& Clohessy, G. R. (2007). Corporate entrepreneurship: An empirical look at individual characteristics, context, and process. Journal of Leadership \& Organizational Studies, 13(4), 40-54.

Hoque, Z. 2005. Linking environmental uncertainty to non-financial performance measures and performance: A research note. The British Accounting Review 37 (4): 471-81.

Hoque, Z., and W. James. 2000. Linking balanced scorecard measures to size and market factors: Impact on organizational performance. Journal of Management Accounting Research 12 (1): 1-17.

Hornsby, J. S., Kuratko, D. F., \& Zahra, S. A. (2002). Middle managers' perception of the internal environment for corporate entrepreneurship: assessing a measurement scale. Journal of business Venturing, 17(3), 253-273.

Hornsby, J. S., \& Kuratko, D. F. (2003). Human resource management in US small businesses: A replication and extension. Journal of developmental entrepreneurship, 8(1), 73.

Hornsby, J. S., Kuratko, D. F., Shepherd, D. A., \& Bott, J. P. (2009). Managers' corporate entrepreneurial actions: Examining perception and position. Journal of business venturing, 24(3), 236-247.

Hotaling, J. M., A. L. Cohen, R. M. Shiffrin, and J. R. Busemeyer. 2015. The dilution effect and information integration in perceptual decision making. PLoS One 10 (9): e0138481.

Hydle, K. M., Aas, T., \& Breuning, K. (2014). Characteristics of intrapreneurs in scaleintensive service firms. Journal of Entrepreneurship, Management and Innovation, 10(2), 89.

Innosight (2018). 2018 Corporate Longevity Forecast: Creative Destruction is Accelerating. Web: https://www.innosight.com/wp-content/uploads/2017/11/InnosightCorporate-Longevity-2018.pdf 
Islam, Z., Doshi, J. A., Mahtab, H., \& Ariffin Ahmad, Z. (2009). Team learning, top management support and new product development success. International Journal of Managing Projects in Business, 2(2), 238-260.

Ireland, R. D., Kuratko, D. F., \& Morris, M. H. (2006). A health audit for corporate entrepreneurship: innovation at all levels: part I. Journal of business strategy.

Ittner, C. D., and D. F. Larcker. 2003. Coming up short on nonfinancial performance measurement. Harvard Business Review 81 (11): 88-95.

Jackall, R. 1988. Moral mazes: The world of corporate managers. International Journal of Politics, Culture, and Society 1 (4): 598-614.

Jørgensen, B., \& Messner, M. (2010). Accounting and strategising: A case study from new product development. Accounting, Organizations and Society, 35(2), 184-204.

Kelley, D. J., Peters, L., \& O'Connor, G. C. (2009). Intra-organizational networking for innovation-based corporate entrepreneurship. Journal of Business Venturing, 24(3), 221-235.

Khandwalla, P. N. (1973). Effect of competition on the structure of top management control. Academy of Management Journal, 16(2), 285-295.

Kuratko, D. F., \& Montagno, R. V. (1989). The intrapreneurial spirit. Training \& Development Journal, 43(10), 83-86.

Kuratko, D. F., Montagno, R. V., \& Hornsby, J. S. (1990). Developing an intrapreneurial assessment instrument for an effective corporate entrepreneurial environment. Strategic management journal, 49-58.

Kuratko, D. F., Covin, J. G., \& Hornsby, J. S. (2014). Why implementing corporate innovation is so difficult. Business Horizons, 57(5), 647-655.

Lam, C. F., DeRue, D. S., Karam, E. P., \& Hollenbeck, J. R. (2011). The impact of feedback frequency on learning and task performance: Challenging the "more is better" assumption. Organizational Behavior and Human Decision Processes, 116(2), 217-228.

Larcker, D. F. 1981. The perceived importance of selected information characteristics for strategic capital budgeting decisions. The Accounting Review 56 (3): 519-38.

Lober, D. J. (1998). Pollution prevention as corporate entrepreneurship. Journal of organizational change management, 11(1), 26-37. 
Low, J., and T. Siesfeld. 1998. Measures that matter: Non-financial performance. Strategy and Leadership 26 (2): 24-38.

Lumpkin, G. T., \& Dess, G. G. (1996). Clarifying the entrepreneurial orientation construct and linking it to performance. Academy of management Review, 21(1), 135-172.

Lumpkin, G. T., \& Dess, G. G. (2001). Linking two dimensions of entrepreneurial orientation to firm performance: The moderating role of environment and industry life cycle. Journal of business venturing, 16(5), 429-451.

Lyon, D. W., Lumpkin, G. T., \& Dess, G. G. (2000). Enhancing entrepreneurial orientation research: Operationalizing and measuring a key strategic decision making process. Journal of management, 26(5), 1055-1085.

Mao, J. C. 1970. Survey of capital budgeting: Theory and practice. The Journal of Finance 25 (2): 349-60.

McKinsey Global Institute. 2017. Overcoming uncertainty, strengthening recovery. New York, NY: McKinsey Global Institute.

McKinsey Global Institute. 2018. Decision-making in your organization-Cutting through the clutter. McKinsey Global, 2018.

Meyvis, T., and C. Janiszewski. 2002. Consumers' beliefs about product benefits: The effect of obviously irrelevant product information. Journal of Consumer Research 28 (4): 61835 .

Millson, M. R., Raj, S. P., \& Wilemon, D. (1992). A survey of major approaches for accelerating new product development. Journal of Product Innovation Management, 9(1), 5369.

Mintzberg, H. (1973). A new look at the chief executive's job. Organizational Dynamics, 1(3), 21-30.

Mohedano-Suanes, A., \& Benítez, D. G. (2018). Intrapreneurs: Characteristics and behavior. In Inside the Mind of the Entrepreneur (pp. 109-119). Springer, Cham.

Morris, M. H., Kuratko, D. F., \& Covin, J. G. (2010). Corporate entrepreneurship \& innovation. Cengage Learning.

Morton, G. H. A. (1983). Become a project champion. International Journal of Project Management, 1(4), 197-203. 
Myers, S. C. 1984. Finance theory and financial strategy. Interfaces 14 (1): 126-37.

Nisbett, R. E., H. Zukier, and R. E. Lemley. 1981. The dilution effect: Nondiagnostic information weakens the implications of diagnostic information. Cognitive Psychology 13 (2): 248-77.

Papadakis, V. M., Lioukas, S., \& Chambers, D. (1998). Strategic decision-making processes: the role of management and context. Strategic management journal, 19(2), 115-147.

Peters, T. J., Waterman, R. H., \& Jones, I. (1982). In search of excellence: Lessons from America's best-run companies.

Phan, P. H., Wright, M., Ucbasaran, D., \& Tan, W. L. (2009). Corporate entrepreneurship: Current research and future directions. Journal of business venturing, 24(3), 197-205.

Piercy, N. F. (Ed.). 2018. The management implications of new information technology, Vol. 41. Routledge.

Pike, R. 1996. A longitudinal survey on capital budgeting practices. Journal of Business Finance and Accounting 23 (1): 79-92.

Pinchot, G. (1985). Intrapreneuring: Why you don't have to leave the corporation to become an entrepreneur. University of Illinois at Urbana-Champaign's Academy for Entrepreneurial Leadership Historical Research Reference in Entrepreneurship.

Pinto, J. K., \& Slevin, D. P. (1987). Critical factors in successful project implementation. IEEE transactions on engineering management, (1), 22-27.

Pinto, M. B., Pinto, J. K., \& Prescott, J. E. (1993). Antecedents and consequences of project team cross-functional cooperation. Management science, 39(10), 1281-1297.

Preacher, K. J., \& Hayes, A. F. (2004). SPSS and SAS procedures for estimating indirect effects in simple mediation models. Behavior research methods, instruments, \& computers, 36(4), 717-731.

Preacher, K. J., \& Hayes, A. F. (2008). Asymptotic and resampling strategies for assessing and comparing indirect effects in multiple mediator models. Behavior research methods, 40(3), 879-891.

Rosemann, M., \& vom Brocke, J. (2015). The six core elements of business process management. In Handbook on business process management 1 (pp. 105-122). Springer, Berlin, Heidelberg. 
Ross, S. A. 1995. Uses, abuses, and alternatives to the net-present-value rule. Financial Management 24 (3): 96-102.

Rutherford, M. W., \& Holt, D. T. (2007). Corporate entrepreneurship: An empirical look at the innovativeness dimension and its antecedents. Journal of organizational change Management, 20(3), 429-446.

Sayeed, O. B., \& Gazdar, M. K. (2003). Intrapreneurship: assessing and defining attributes of intrapreneurs. The Journal of Entrepreneurship, 12(1), 75-89.

Schuler, R. S. (1986). Fostering and facilitating entrepreneurship in organizations: Implications for organization structure and human resource management practices. Human resource management, 25(4), 607-629.

Schumpeter, J. A. (1911). The theory of economic development (Theorie der wirtschaftlichen Entwicklung).

Shanteau, J. 1992. How much information does an expert use? Is it relevant? Acta Psychologica 81 (1): 75-86.

Sharda, R., S. H. Barr, and J. C. McDonnell. 1988. Decision support system effectiveness: A review and an empirical test. Management Science 34 (2): 139-59.

Shelton, S. W. 1999. The effect of experience on the use of irrelevant evidence in auditor judgment. The Accounting Review 74 (2): 217-24.

Slevin, D. P., \& Covin, J. G. (1990). Juggling entrepreneurial style and organizational structure. MIT Sloan Management Review, 31(2), 43.

Smith, W. K., \& Tushman, M. L. (2005). Managing strategic contradictions: A top management model for managing innovation streams. Organization science, 16(5), 522-536.

Song, X. M., \& Montoya-Weiss, M. M. (1998). Critical development activities for really new versus incremental products. Journal of Product Innovation Management, 15(2), 124-135.

Sprinkle, G. B. 2003. Perspectives on experimental research in managerial accounting. Accounting, Organizations and Society 28 (2-3): 287-318.

Srivastava, A., \& Lee, H. (2005). Predicting order and timing of new product moves: the role of top management in corporate entrepreneurship. Journal of Business Venturing, 20(4), 459-481. 
Sumner, M. (1999). Critical success factors in enterprise wide information management systems projects. AMCIS 1999 Proceedings, 83.

Sundbo, J. (1999). Empowerment of employees in small and medium-sized service firms. Employee Relations, 21(2), 105-127.

Sundem, G. L. 1975. Evaluating capital budgeting models in simulated environments. The Journal of Finance 30 (4): 977-92.

Swain, M. R., and S. F. Haka. 2000. Effects of information load on capital budgeting decisions. Behavioral Research in Accounting 12: 171-99.

Swink, M. L., Sandvig, J. C., \& Mabert, V. A. (1996). Customizing concurrent engineering processes: five case studies. Journal of Product Innovation Management, 13(3), 229-244.

Swink, M. (2000). Technological innovativeness as a moderator of new product design integration and top management support. Journal of Product Innovation Management, 17(3), 208-220.

Sykes, A. O. (1984). The economics of vicarious liability. The Yale Law Journal, 93(7), 1231-1280.

Sykes, H. B. (1986). The anatomy of a corporate venturing program: Factors influencing success. Journal of Business Venturing, 1(3), 275-293.

Takeuchi, H., \& Nonaka, I. (1986). The new new product development game. Harvard business review, 64(1), 137-146.

Tam, K. Y. (1992). Capital budgeting in information systems development. Information \& Management, 23(6), 345-357.

Tatikonda, M. V., \& Rosenthal, S. R. (2000). Technology novelty, project complexity, and product development project execution success: a deeper look at task uncertainty in product innovation. IEEE Transactions on engineering management, 47(1), 74-87.

Tetlock, P. E., and R. Boettger. 1989. Accountability: A social magnifier of the dilution effect. Journal of Personality and Social Psychology 57 (3): 388-98.

Thong, J. Y., Yap, C. S., \& Raman, K. S. (1996). Top management support, external expertise and information systems implementation in small businesses. Information systems research, 7(2), 248-267. 
Troutman, C. M., and J. Shanteau. 1977. Inferences based on nondiagnostic information. Organizational Behavior and Human Performance 19 (1): 43-55.

Turner, M. J., and L. V. Coote. 2018. Incentives and monitoring: impact on the financial and non-financial orientation of capital budgeting. Meditari Accountancy Research 26 (1): 12244.

Tversky, A., and D. Kahneman. 1973. Availability: A heuristic for judging frequency and probability. Cognitive Psychology 5 (2): 207-32.

Tversky, A., \& Kahneman, D. (1974). Judgment under uncertainty: Heuristics and biases. science, 185(4157), 1124-1131.

Van den Ende, J., Wijnberg, N., Vogels, R., \& Kerstens, M. (2003). Organizing Innovative Projects to Interact with Market Dynamics:: A Coevolutionary Approach. European Management Journal, 21(3), 273-284.

Verbeeten, F. H. 2006. Do organizations adopt sophisticated capital budgeting practices to deal with uncertainty in the investment decision? A research note. Management Accounting Research 17 (1): 106-20.

Viswesvaran, C., Deshpande, S. P., \& Joseph, J. (1998). Job satisfaction as a function of top management support for ethical behavior: A study of Indian managers. Journal of Business Ethics, 17(4), 365-371.

Waller, W. S., and M. F. Zimbelman. 2003. A cognitive footprint in archival data: Generalizing the dilution effect from laboratory to field settings. Organizational Behavior and Human Decision Processes 91 (2): 254-68.

Whitney, P., Rinehart, C. A., \& Hinson, J. M. (2008). Framing effects under cognitive load: The role of working memory in risky decisions. Psychonomic bulletin \& review, 15(6), 1179-1184.

Wu, S., Levitas, E., \& Priem, R. L. (2005). CEO tenure and company invention under differing levels of technological dynamism. Academy of Management Journal, 48(5), 859-873.

Yin, R. K. (2006). Mixed methods research: Are the methods genuinely integrated or merely parallel. Research in the Schools, 13(1), 41-47.

Young, R., \& Jordan, E. (2008). Top management support: Mantra or necessity?. International journal of project management, 26(7), 713-725.

Zahra, S. A. (1991). Predictors and financial outcomes of corporate entrepreneurship: An exploratory study. Journal of business venturing, 6(4), 259-285. 
Zirger, B. J., \& Maidique, M. A. (1990). A model of new product development: An empirical test. Management science, 36(7), 867-883. 
6. Appendix A - Experimental details chapter 2

6.1 Part 1 - Experimental flow (exemplary treatment of high risk and 12 information cues)

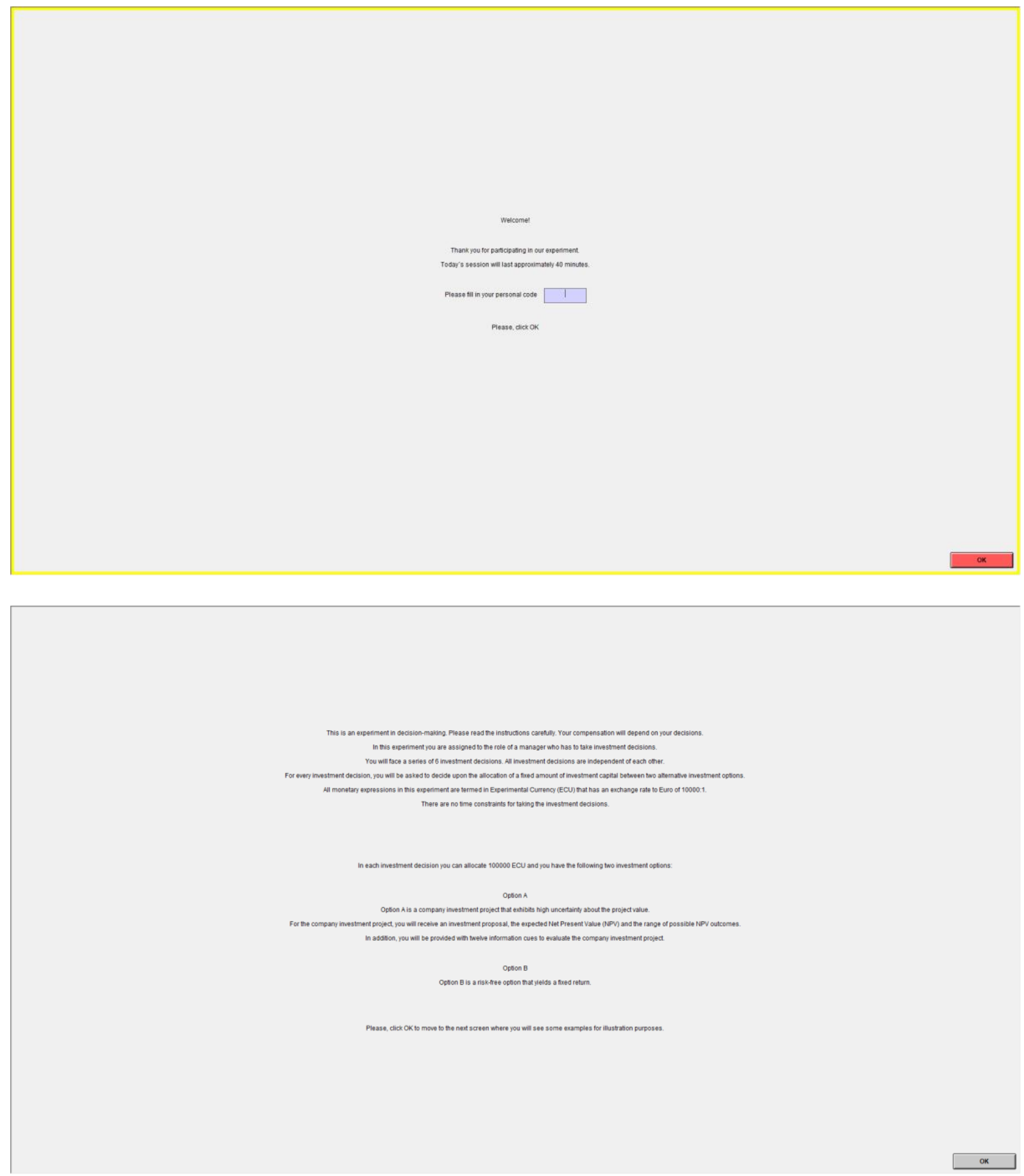




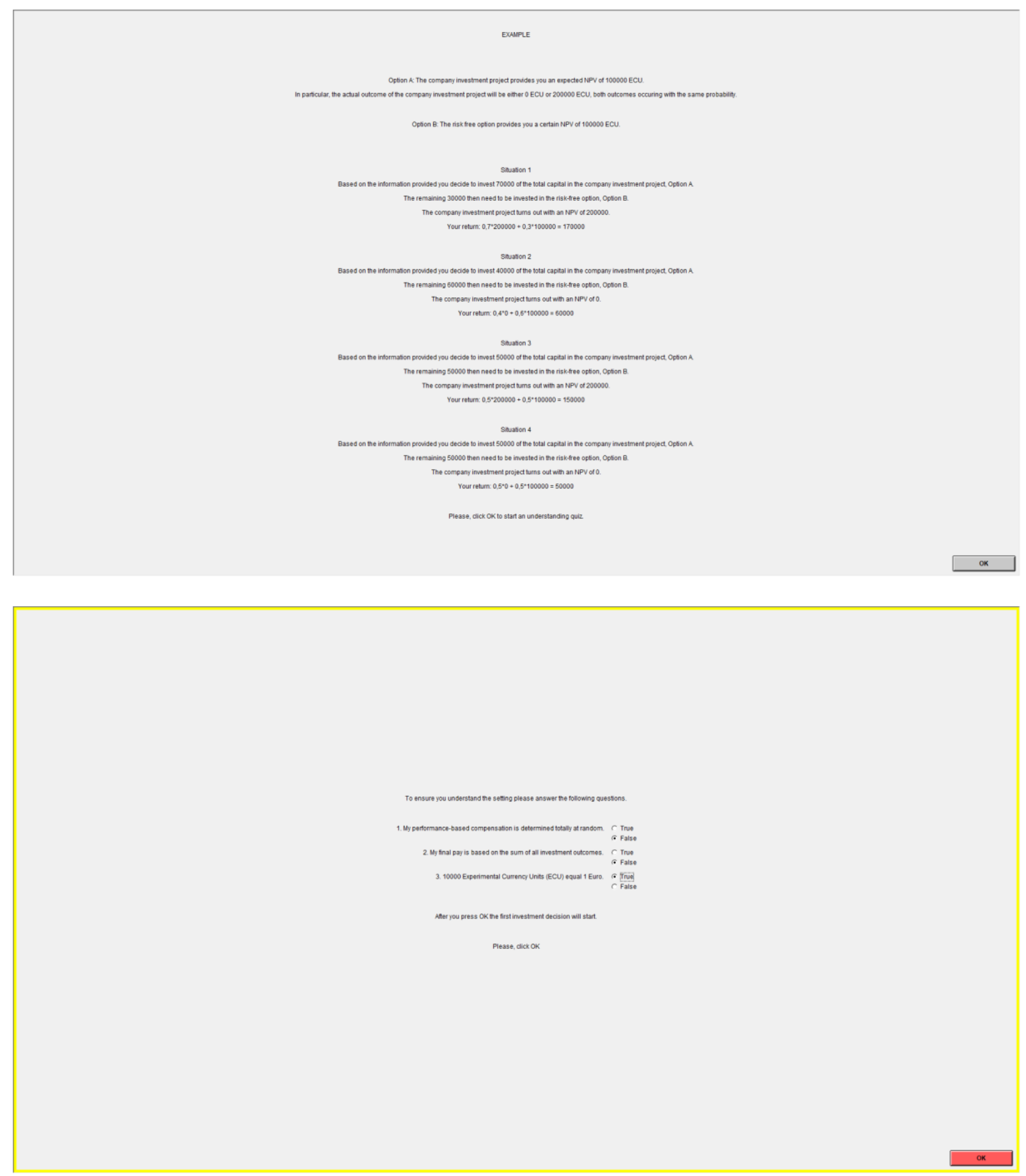




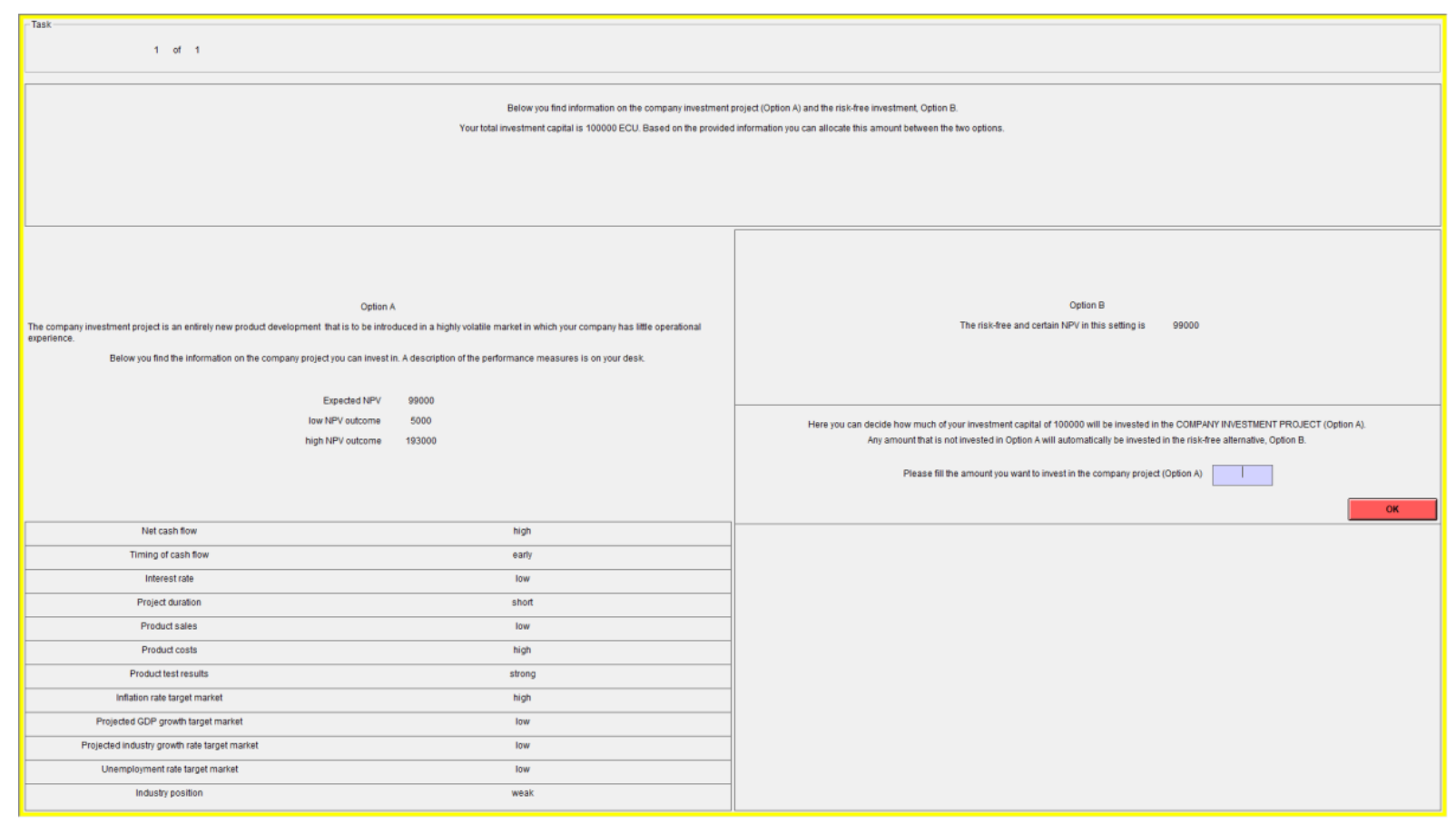

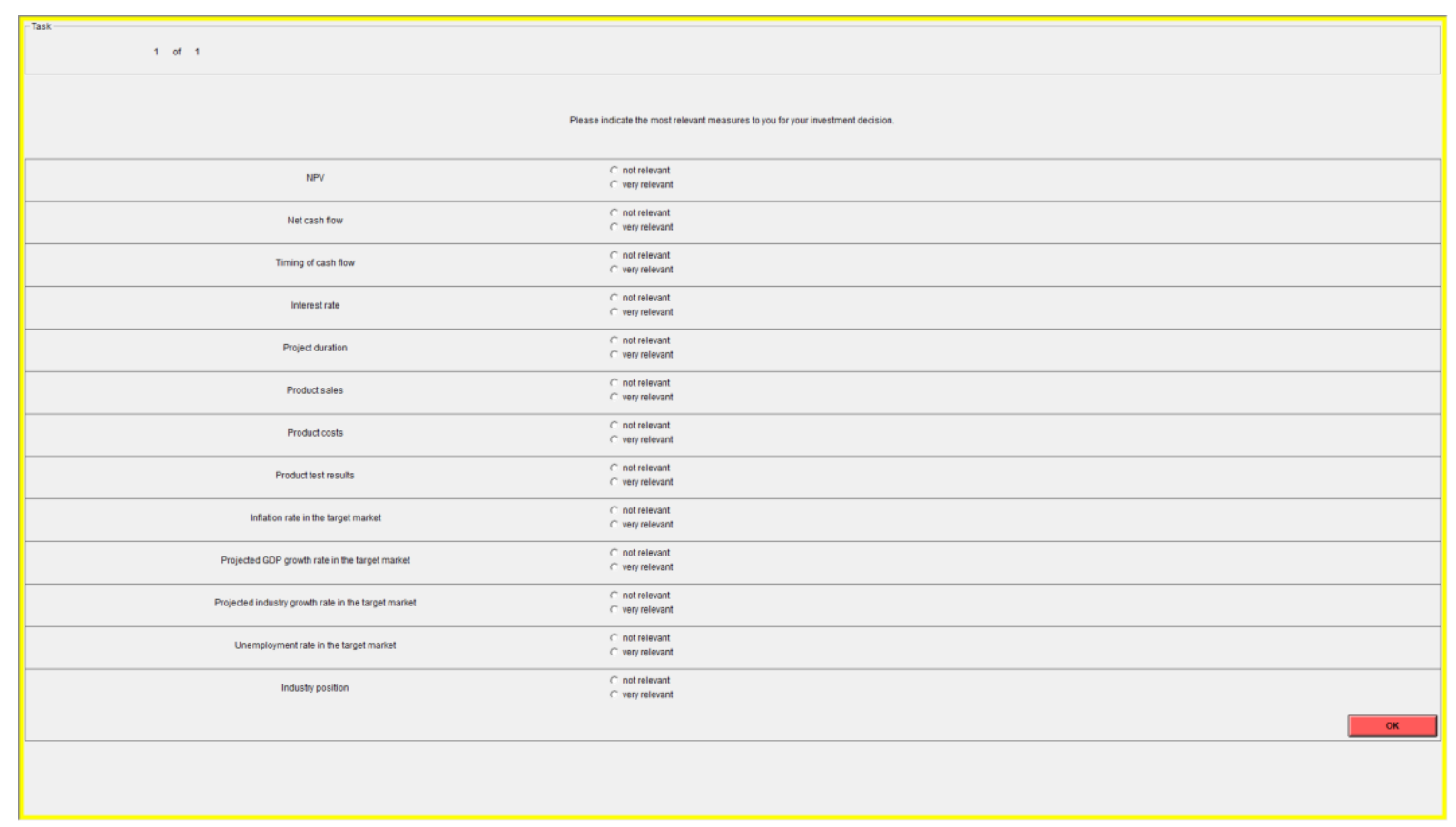




\subsection{Part 2 - Post experimental questionnaire}

\section{Post Experiment Questionnaire}

Please fill in the questionnaire below as final part of the experiment you participated in. Thank you very much.

Your experimental ID number:

1. I perceive the context I was assigned to as being highly uncertain

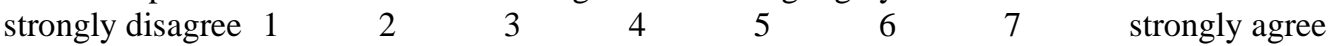

2. I am __ years old.

3. I am

Male

Female

Other

4. My nationality is

5. I am familiar with the concept of Net cash flow

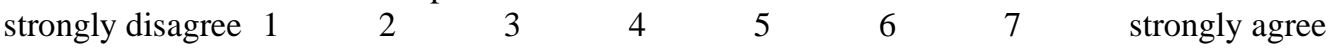

6. I am familiar with the concept of Timing of cash flow

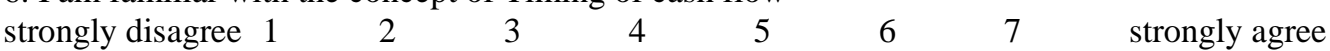

7. I am familiar with the concept of Interest Rate

$\begin{array}{lllllllll}\text { strongly disagree } & 1 & 2 & 3 & 4 & 5 & 6 & 7 & \text { strongly agree }\end{array}$

8. I am familiar with the concept of Project duration

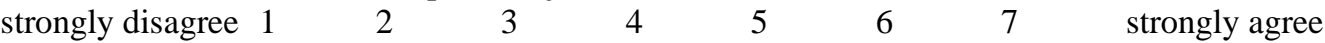

9. I am familiar with the concept of Product sales

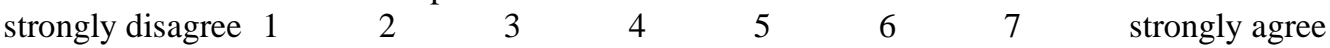

10. I am familiar with the concept of Product costs

$\begin{array}{lllllllll}\text { strongly disagree } & 1 & 2 & 3 & 4 & 5 & 6 & 7 & \text { strongly agree }\end{array}$

11. I am familiar with the concept of Product test results

$\begin{array}{lllllllll}\text { strongly disagree } & 1 & 2 & 3 & 4 & 5 & 6 & 7 & \text { strongly agree }\end{array}$

12. I am familiar with the concept of Projected GDP growth rate in the target market $\begin{array}{lllllllll}\text { strongly disagree } & 1 & 2 & 3 & 4 & 5 & 6 & 7 & \text { strongly agree }\end{array}$

13. I am familiar with the concept of Projected industry growth rate in the target market $\begin{array}{lllllllll}\text { strongly disagree } & 1 & 2 & 3 & 4 & 5 & 6 & 7 & \text { strongly agree }\end{array}$ 14. I am familiar with the concept of Inflation rate in the target market $\begin{array}{lllllllll}\text { strongly disagree } & 1 & 2 & 3 & 4 & 5 & 6 & 7 & \text { strongly agree }\end{array}$ 15. I am familiar with the concept of Unemployment rate in the target market

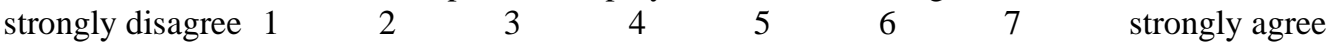

16. I am familiar with the concept of Industry position $\begin{array}{lllllllll}\text { strongly disagree } & 1 & 2 & 3 & 4 & 5 & 6 & 7 & \text { strongly agree }\end{array}$

17. I am familiar with taking investment decisions 
$\begin{array}{lllllllll}\text { strongly disagree } & 1 & 2 & 3 & 4 & 5 & 6 & 7 & \text { strongly agree }\end{array}$

18. The experiment was easy to comprehend

$\begin{array}{lllllllll}\text { strongly disagree } & 1 & 2 & 3 & 4 & 5 & 6 & 7 & \text { strongly agree }\end{array}$

19. I feel that I received enough information

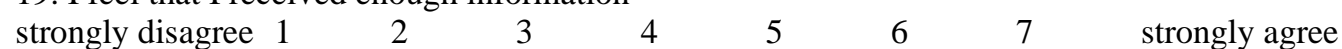

20. I feel that I received too much information

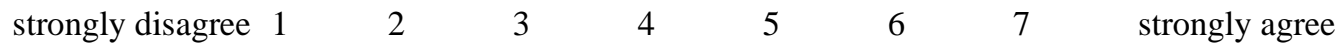

21. I enjoyed the experiment

$\begin{array}{lllllllll}\text { strongly disagree } & 1 & 2 & 3 & 4 & 5 & 6 & 7 & \text { strongly agree }\end{array}$

22. I have strong analytical skills

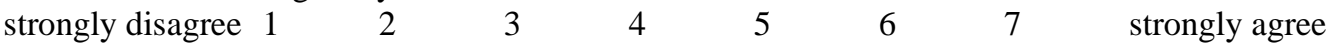

23. Assume you are working full time for a company. You are compensated with a fixed salary of $€ 1500$,per month. Furthermore assume you had the choice between the following alternatives for the next month:

Alternative 1: $\quad$ You will earn again $€ 1500$,- with certainty.

Alternative 2: $\quad$ You will earn $€ 1200$ with certainty and with a probability $\mathrm{p}$ you will receive an additional bonus of $€ 600,-$.

How large must the probability p be for you to accept alternative 2 ?

24. In this experiment, I have tried to maximize my pay off.

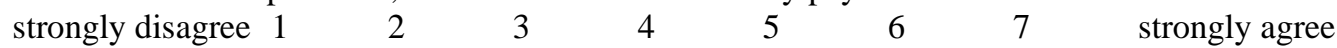




\section{Appendix B - Survey details chapter 3}

\subsection{Part 1 - Questionnaire outline for intrapreneurship program managers}

\begin{tabular}{cl}
\hline & Questionnaire outline for intrapreneurship program managers \\
\hline Item & Questions \\
\hline 1 & What is your definition of intrapreneurship? \\
2 & Who is in charge of the intrapreneurship program in your firm? \\
3 & What is the objective of intrapreneurship program? \\
4 & Who is eligible to become part of the intrapreneurship program? \\
5 & How is the intrapreneurship program governed? \\
6 & How is the intrapreneurship program structured? \\
7 & What does the intrapreneurship program encompass? \\
8 & How is the top management involved in the intrapreneurship program? \\
9 & How is the board of management involved in the intrapreneurship program? \\
10 & How much time do intrapreneurs have to pursue their projects? \\
11 & How much autonomy do intrapreneurs have in your program? \\
12 & Are intrapreneurs encourage to work in interdisciplinary teams? If so, how? \\
13 & How are intrapreneurs incentivized in the program? \\
14 & How are intrapreneurship projects monitored in your organization? \\
15 & How is the success of the program measured? \\
\hline
\end{tabular}


7.2 Part 2 - Survey items for intrapreneur questionnaire

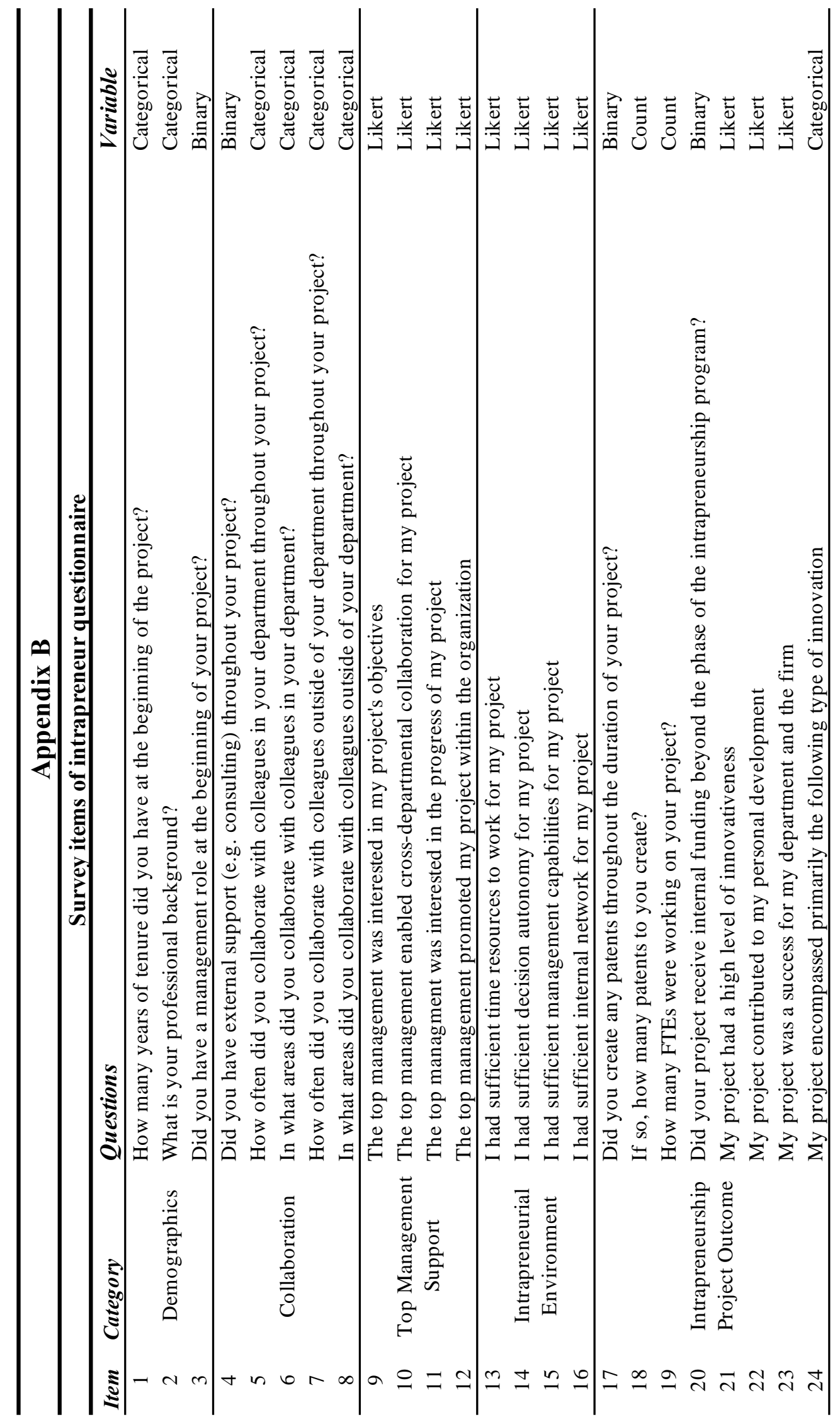


7.3 Part 3 - OLS Regression Models \& Sobel Test Mediation

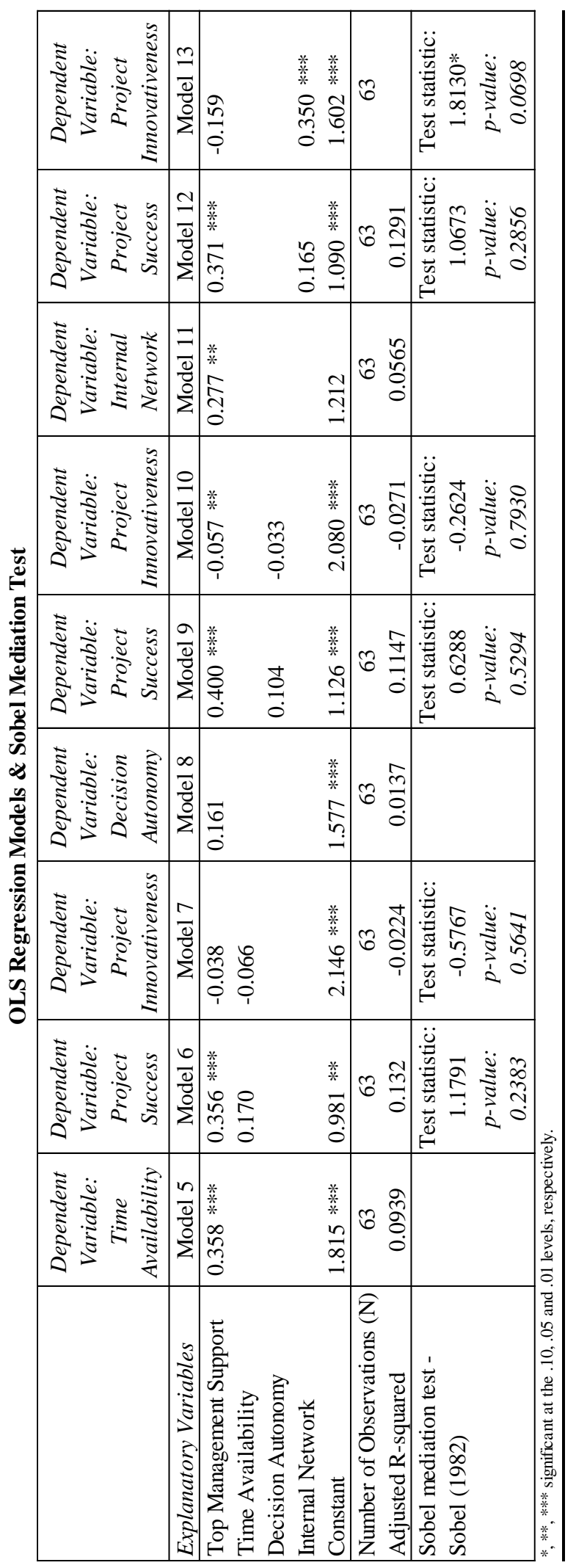




\section{Appendix C: Valorization-addendum}

Dynamical changing market conditions require organizations to continuously adapt. This does not merely affect a firm's market-facing product line, but rather its organizational versatility to adjust to any given market environment as quickly as possible. While over the past decades, the ascent of multinational firms has been primarily attributed to the ability to deliver a particular product or service range at consistent quality for a competitive price; today's growth leaders are information-driven powerhouses that compete on innovativeness and speed. Hence, too big to fail is outdated; too quick to fail is the new paradigm.

In light of this paradigm shift, the studies in my dissertation analyze two crucial components that allow organizations to persist under dynamic market circumstances. First, I analyze capital budgeting decision for innovation projects in face of risk and information abundance and how that alters decision-making behavior. Second, I delineate the role of top management in facilitating intrapreneurial undertakings as a means to innovate in an established organization. Nowadays, decision-makers face an overabundance of information. Navigating through large amounts of information to determine what information is diagnostic for a decision outcome, and what is not, is not only effortful, but can also bear the risk that decision-makers consider nondiagnostic information in a decision task. In this dissertation I show that this deficiency exists in capital budgeting decisions for innovation projects and that decision-makers take nondiagnostic information into account when exposed to it. As a consequence, capital budgeting decision dilute, such that decision-makers allocate less funds to projects when taking nondiagnostic information into account, even more so with an increasing amount of nondiagnostic information available. To ensure that decision-makers allocate adequate funds to innovation projects, companies need to reevaluate the amount and breadth of information utilized in capital budgeting decision. Although a general tendency to include as much information as possible in order to take an informed decision, my results show that there are 
limits. More is not necessarily better, it is more important to provide selected and relevant information that decision-makers can process effectively in capital budgeting tasks.

Further, my research suggests that decision-makers tend to exhibit a preference for familiar information cues when it comes to an overabundance of information causing cognitive load. This is particularly relevant for strategic decisions where different types of information, for instance financial and non-financial, are integral part of the decision-making process. An individual preference under difficult circumstances such as risk or cognitive load may cause suboptimal decisions, thereby endangering a company's long-term success. Particularly for decisions of strategy or budget allocation where information load is high, firms are well-advised to ensure that decision-makers review all relevant information and not limit the sight on familiar cues. This can for example be achieved through an adequate management information system that directs decision-makers attention relevant information and does not permit to limit attention on familiar information cues.

While effective capital budgeting decision-making under risk and cognitive load are crucial for the success of a company, so is the execution of funded innovation projects. One way of driving innovation projects is by facilitating intrapreneurial activity, so encouraging entrepreneurs in an existing organization to thrive. In my dissertation, I analyzed the role of top managers to increase the impact of intrapreneurship in an organization. As intrapreneurial activity is commonly a bottom-up initiative, it is extremely important that top managers create an environment that supports intrapreneurs as innovators rather than an alien to the core business. My research shows that top managers can support intrapreneurial projects through promoting and engaging the intrapreneur. It shows that these initiatives yield more successful results when top management support is provided in order to overcome obstacles in an established organization. This is particularly important when inertia has built up over time and any doubt about the ongoing core business is not permitted by anyone. Top managers need to safeguard 
these doubters and intrapreneurs in order to remain competitive in the long-run and tap into novel revenue streams.

At the same time, however, top managers should not become too committed in an intrapreneurial project. Because what starts out as support may turn into interference with the actual intrapreneurs work such that the innovativeness of the undertakings is actually reduced. This can stem from a lack of understanding, which is especially severe in technology areas, where top managers' technical expertise may not be comprehensive enough to grasp an intrapreneur's business idea. Also, top managers' short-sighted incentive schemes may also hamper with the innovativeness of intrapreneurship projects. While innovations usually take immense financial effort with payback in very distant future, top managers may urge intrapreneurs to not aim for a long shot, but rather focus on the near-term impact of the initiative. Hence, top managers should balance their support depending on the situation to ensure that the projects have a chance to be successful within the organization, while also making sure that time and resources are provided to permit the realization of long-term objectives.

Lastly, it is important to create an environment for intrapreneurs to excel with their projects. My research shows that this is not limited to time and financial resources that need to be provided to intrapreneurs, but it is also about personal networks. From the interview and survey evidence, it can be inferred that especially in large organization a personal network is crucial for intrapreneurial undertakings to be successful. Given that not every intrapreneur has an intraorganizational network, it is important that top managers act as catalyst to bring the right people together in order to make innovation happen, but also safeguarding a smooth execution of the intrapreneurship project.

To sum up, the three studies of this dissertation examine capital budgeting decisions for innovation projects under risk and information overabundance as well as the top management 
role in the execution of innovative intrapreneurship projects. All studies have direct practical implications for top managers and corporate decision-makers. With my dissertation I contribute a better understanding of the behavior of decision-makers under challenging conditions, which allows organizations to mediate this behavior in order to prevent suboptimal decisions. Further, I provide insights in the role of top managers to allow intrapreneurs to successfully pursue innovative undertakings thereby contributing to overall long-term firm performance. 


\section{Curriculum Vitae}

Benedikt Stolze was born on December $11^{\text {th }}, 1989$ in Osnabrück, Germany. For his preuniversity education, he attended Copenhagen International School (Denmark) and Bettinavon-Arnim Gymnasium (Germany) until 2009. From 2010 to 2014 he studied business administration (specializations finance \& management) at Westfälische Wilhelms-Universität Münster (Germany) and Dublin Business School (Ireland). During his bachelor's studies he interned with Nukem Isotopes $\mathrm{GmbH}$, Daimler AG and Porsche Consulting GmbH. Before commencing with his master's studies, he worked at Warth \& Klein Grant Thornton AG and completed his first level of the CFA. In September 2014, he began his master's studies in international business (specialization strategy \& innovation) at Maastricht University (the Netherlands) and Indian Institute of Management Ahmedabad (India). In 2016, he became a $\mathrm{PhD}$ candidate at Maastricht University in the department of Accounting and Information Management. At the same time, he started his role as a project manager in the area of smart mobility at Volkswagen AG. During his doctoral studies, he presented his work at various accounting conferences. Since 2018, he works as management consultant with Porsche Consulting $\mathrm{GmbH}$ in their Berlin office. In 2019, he also founded Urbeee $\mathrm{GmbH}$, a start-up that develops a quality-oriented operating model for last mile delivery. 